\title{
Review \\ miRNA Clusters with Up-Regulated Expression in Colorectal Cancer
}

\author{
Paulína Pidíková and Iveta Herichová *
}

Citation: Pidíková, P.; Herichová, I. miRNA Clusters with Up-Regulated Expression in Colorectal Cancer. Cancers 2021, 13, 2979. https:// doi.org/10.3390/cancers13122979

Academic Editors: Ion Cristobal and Cristina Carames

Received: 28 April 2021

Accepted: 9 June 2021

Published: 14 June 2021

Publisher's Note: MDPI stays neutral with regard to jurisdictional claims in published maps and institutional affiliations.

Copyright: (c) 2021 by the authors. Licensee MDPI, Basel, Switzerland. This article is an open access article distributed under the terms and conditions of the Creative Commons Attribution (CC BY) license (https:/ / creativecommons.org/licenses/by/ $4.0 /)$.
Department of Animal Physiology and Ethology, Faculty of Natural Sciences, Comenius University in Bratislava, Ilkovičova 6, 84215 Bratislava, Slovakia; paulina.pidikova@uniba.sk

* Correspondence: iveta.herichova@uniba.sk; Tel.: +421-602-96-572

Simple Summary: As miRNAs show the capacity to be used as CRC biomarkers, we analysed experimentally validated data about frequently up-regulated miRNA clusters in CRC tissue. We identified 15 clusters that showed increased expression in CRC: miR-106a/363, miR-106b/93/25, miR-17/92a-1, miR-181a-1/181b-1, miR-181a-2/181b-2, miR-181c/181d, miR-183/96/182, miR-191/425, miR-200c/141, miR-203a/203b, miR-222/221, mir-23a/27a/24-2, mir-29b-1/29a, mir-301b/130b and mir-452/224. Cluster positions in the genome are intronic or intergenic. Most clusters are regulated by several transcription factors, and by long non-coding RNAs. In some cases, co-expression of miRNA with other cluster members or host gene has been proven. miRNA expression patterns in cancer tissue, blood and faeces were compared. The members of the selected clusters target 181 genes. Their functions and corresponding pathways were revealed with the use of Panther analysis. Clusters miR-17/92a-1, miR-106a/363, miR-106b/93/25 and miR-183/96/182 showed the strongest association with metastasis occurrence and poor patient survival, implicating them as the most promising targets of translational research.

Abstract: Colorectal cancer (CRC) is one of the most common malignancies in Europe and North America. Early diagnosis is a key feature of efficient CRC treatment. As miRNAs can be used as CRC biomarkers, the aim of the present study was to analyse experimentally validated data on frequently up-regulated miRNA clusters in CRC tissue and investigate their members with respect to clinicopathological characteristics of patients. Based on available data, 15 up-regulated clusters, miR-106a/363, miR-106b/93/25, miR-17/92a-1, miR-181a-1/181b-1, miR-181a-2/181b-2, miR-181c/181d, miR-183/96/182, miR-191/425, miR-200c/141, miR-203a/203b, miR-222/221, mir-23a/27a/24-2, mir-29b-1/29a, mir-301b/130b and mir-452/224, were selected. The positions of such clusters in the genome can be intronic or intergenic. Most clusters are regulated by several transcription factors, and miRNAs are also sponged by specific long non-coding RNAs. In some cases, co-expression of miRNA with other cluster members or host gene has been proven. miRNA expression patterns in cancer tissue, blood and faeces were compared. Based on experimental evidence, 181 target genes of selected clusters were identified. Panther analysis was used to reveal the functions of the target genes and their corresponding pathways. Clusters miR-17/92a-1, miR-106a/363, miR-106b/93/25 and miR-183/96/182 showed the strongest association with metastasis occurrence and poor patient survival, implicating them as the most promising targets of translational research.

Keywords: metastases; survival; oncogenes; tumour suppressors; miR-17/92a-1; miR-183/96/182

\section{Introduction}

The present systematic review is focused on clusters of micro RNAs (miRNAs) with up-regulated expression in colorectal cancer (CRC) tissue showing potential for use as biomarkers. The improvement of CRC diagnosis and treatment is still a pressing issue, as CRC is the third most commonly diagnosed cancer and the second most frequent cause of cancer death worldwide. The highest CRC incidence rate has been revealed in Europe 
(predominantly Western and Northern Europe), Australia, New Zealand, North America and East Asia. The incidence of CRC has increased mainly in the younger population (up to 55 years) in last two decades [1].

miRNAs are a class of small non-coding RNAs with a length of approximately $20 \mathrm{bp}[2,3]$. Several miRNAs are already used in clinics as a diagnostic tool and/or in cancer treatment [4]. Biosynthesis of miRNAs consists of two processing steps. First, the primary miRNA transcript (pri-miRNA) is processed in the nucleus by the protein complex microprocessor containing the enzyme Drosha and the cofactor DGCR8 to generate a precursor miRNA (pre-miRNA). The second processing step, executed by the enzyme Dicer and its cofactors TAR (HIV-1) RNA binding protein 2 (TARBP2) and protein activator of interferon induced protein kinase EIF2AK2 (PRKRA), occurs after pre-miRNA transport to the cytoplasm. Expression of Drosha, Dicer and DGCR8 has been shown to be up-regulated in colorectal adenocarcinoma, compared with non-neoplastic tissue [5]. Moreover, increased expression of the enzymes Dicer [6], Drosha and cofactor TARBP2 [7] was associated with worse survival. The role of Dicer in CRC progression is also supported by the finding that oxaliplatin treatment is associated with a decrease in Dicer levels in human CRC cells [8]. However, enzymes of the miRNA biosynthesis pathway do not seem to be the most important factor determining the up-regulation of miRNA expression in cancer tissue [6], and transcription regulation seems to be more important in this respect. The rate of expression depends on regulatory regions of miRNA genes located in intergenic areas or host genes of intragenic miRNAs. Intragenic miRNAs are located in intron or exon areas of their host genes, and thus, they make coordinated transcription of host gene and miRNA possible [9-11].

Therefore, we performed a screen of miRNA clusters up-regulated in CRC tissue and focused on the correlation of their expression with clinicopathological characteristics, patient prognosis, response to therapy and survival. miRNA locations in the genome were analysed to assess possible modes of regulation of their expression. The functions of the target genes of selected up-regulated miRNA clusters in human CRC cell lines were also studied using in silico research tools to determine if their up-regulation contributes to CRC progression. On the basis of the obtained results, modes of regulation and functions of specific miRNA clusters were determined.

\section{Materials and Methods}

\subsection{Literature Search Strategy}

The PubMed and Scopus databases were searched to find research papers referring to miRNA expression screening in colorectal cancer tissue. Research articles published up to 12 September 2020 were collected. The search terms used were ("colorectal cancer") AND ([miRNA expression profile] OR [microRNA expression profile]) AND ([upregulation] OR [up-regulation]). In preliminary screening, duplicate articles were omitted.

\subsubsection{Eligibility Criteria for Articles}

The criteria for inclusion of articles were as follows:

1. Studies published in the English language

2. Studies with samples of human tumour tissue from patients with CRC

3. Studies where the miRNA expression profile of the CRC tumour tissue was compared with that of normal tissue

4. Studies with available expression data about up-regulated miRNAs

The criteria for exclusion of articles were as follows:

1. Reviews, book chapters, meta-analysis, and systematic reviews

2. Studies using only animal models and cell lines

3. Studies where only plasma or serum samples from patients with CRC were analysed. 


\subsubsection{Eligibility Criteria for Selecting miRNAs and miRNA Clusters}

For further analyses, only those miRNA clusters where the majority of their members had been reported in three or more studies were selected. In the next step, the genome location of selected miRNA clusters was investigated. Only miRNA clusters located on the same DNA strand, where the distance between miRNAs in one cluster was lower than $10 \mathrm{kbp}$, were included in the study.

\subsection{Searching for Further Data about miRNAs}

In the next step, we searched the PubMed database for articles about selected miRNAs involved in clusters that met the inclusion criteria. We focused on studies analysing the expression of selected miRNAs in human CRC tissues, the circulation or stool. Associations of miRNA expression with clinicopathological characteristics and target genes of selected miRNAs, validated in human CRC cells lines, were also extracted from these articles. In this way, 418 references were included into study.

\subsection{Classification of Target Genes by Panther Analysis}

In vitro experimentally validated target genes of miRNA clusters up-regulated in CRC were classified with the Gene Ontology (GO) Analysis Panther Classification System (GO database Version 16.0 released 1 December 2020) [12]. Genes were grouped according to four classification categories: molecular function, biological process, protein class and pathway. An overrepresentation test was also used to identify enriched categories in each classification. Statistical significance was evaluated using Fisher's exact test and the calculated false discovery rate (FDR). The GO-Slim and Panther Pathway categories with $p<0.05$ and an FDR $<0.05$ were considered statistically significant.

\section{Results}

\subsection{Characteristic of Studies Involved in Meta-Analysis}

In total, 225 studies were found using the PubMed database, and 174 studies were found using Scopus. In preliminary screening, we omitted 99 duplicated articles. In the next step, according to the inclusion and exclusion criteria, we included 47 articles in our study. The searching process is depicted in Figure 1. The included studies are listed in Supplementary Material S1. A total of 496 up-regulated miRNAs were reported in the selected studies; among them, 107 mature miRNAs were reported in three or more studies.

From these 107 miRNAs, we selected 64 mature miRNAs which were located in clusters. According to the selection criteria, 15 miRNA clusters with up-regulated miRNA in CRC tissues were included in the study.

The miRNA clusters included in the study are listed below. Cluster miR-106a/18b/20b /19b-2/92a-2/363 is abbreviated in further text as miR-106a/363 and cluster miR-17/18a $/ 19 \mathrm{a} / 20 \mathrm{a} / 19 \mathrm{~b}-1 / 92 \mathrm{a}-1$ is abbreviated as miR-17/92a-1.

- $\mathrm{miR}-106 \mathrm{a} / 18 \mathrm{~b} / 20 \mathrm{~b} / 19 \mathrm{~b}-2 / 92 \mathrm{a}-2 / 363$ (miR-106a/363)

- $\operatorname{miR}-106 b / 93 / 25$

- $\operatorname{miR}-17 / 18 a / 19 a / 20 a / 19 b-1 / 92 a-1$ (miR-17/92a-1)

- miR-181a-1/181b-1

- miR-181a-2/181b-2

- $\operatorname{miR}-181 \mathrm{c} / 181 \mathrm{~d}$

- $\operatorname{miR}-183 / 96 / 182$

- $\operatorname{miR}-191 / 425$

- $\quad \mathrm{miR}-200 \mathrm{c} / 141$

- $\mathrm{miR}-203 \mathrm{a} / 203 \mathrm{~b}$

- $\mathrm{miR}-222 / 221$

- $\operatorname{miR}-23 a / 27 a / 24-2$

- $\operatorname{miR}-29 b-1 / 29 a$

- $\mathrm{miR}-301 \mathrm{~b} / 130 \mathrm{~b}$

- $\operatorname{miR}-452 / 224$ 




Figure 1. Study flow diagram of selection for up-regulated miRNA clusters.

Next, we closely analysed the selected miRNAs according to their location in the human genome, their expression in human CRC samples and their association with clinicopathological characteristics. Only those target genes of miRNAs that have been validated in experimental studies were included in the study. Afterwards, target genes were classified according to GO-Slim Panther analyses, and an overrepresentation test [12] was used to reveal significantly enriched categories in each Panther classification category.

\subsection{Genomic Location of Selected Clusters and Regulation of Their Expression}

Comprehensive analysis of clusters with up-regulated expression in CRC tissue revealed that eight clusters are located in intronic areas of protein-coding genes. Another seven clusters are located in intergenic regions. This distribution agrees with previously published studies, which revealed that approximately one half of miRNAs in the human genome are located in intronic areas of genes [11,13]. On the other hand, our previous study revealed that miRNA clusters with down-regulated expression are predominantly located in intronic areas of genes [14]. All selected clusters and their host genes are listed in Table 1. 
Table 1. Host gene and genomic location of miRNA clusters.

\begin{tabular}{|c|c|c|c|c|}
\hline $\begin{array}{l}\text { Cluster } \\
\text { Chromosome }\end{array}$ & $\begin{array}{l}\text { Host } \\
\text { Gene/Locus } \\
\text { Name }\end{array}$ & Host Gene Type & $\begin{array}{l}\text { Cluster } \\
\text { Location }\end{array}$ & $\begin{array}{l}\text { Expression Regulation and } \\
\text { Transcription Site (TSS) }\end{array}$ \\
\hline $\begin{array}{c}\operatorname{miR}-106 a / 18 b / 20 b / 19 b-2 / 92 a-2 \\
\text { chr. } X\end{array}$ & $\begin{array}{c}X q 26.2 \\
{[15]}\end{array}$ & Non-coding & intergenic & Own TSS [10] \\
\hline $\begin{array}{c}\mathrm{miR}-106 \mathrm{~b} / 93 / 25 \\
\text { chr. } 7\end{array}$ & $\begin{array}{c}\mathrm{MCM} 7 \\
{[15]}\end{array}$ & Protein coding & intron & $\begin{array}{c}\text { Co-expression of miR-25 with the } \\
\text { host gene [16]. Host gene TSS } \\
{[17-19]}\end{array}$ \\
\hline $\begin{array}{c}\operatorname{miR}-17 / 18 a / 19 a / 20 a / 19 b-1 / 92 a-1 \\
\text { chr.13 }\end{array}$ & $\begin{array}{l}\text { MIR17HG } \\
\text { [15] }\end{array}$ & Long non-coding & intron & $\begin{array}{c}\text { Co-expression of miR-17, miR-18a, } \\
\text { miR-20a and miR-92a with the } \\
\text { host gene }[16,20] . \text { Multiple TSS } \\
{[10,11]}\end{array}$ \\
\hline $\begin{array}{l}\operatorname{miR}-181 \mathrm{a}-1 / 181 \mathrm{~b}-1 \\
\text { chr. } 1\end{array}$ & $\begin{array}{l}\text { MIR181A1HG } \\
{[21]}\end{array}$ & Long non-coding & intron & Multiple TSS [10] \\
\hline $\begin{array}{c}\operatorname{miR}-181 \mathrm{a}-2 / 181 \mathrm{~b}-2 \\
\text { chr. } 9\end{array}$ & $\begin{array}{l}\text { NR6A1 } \\
\text { [22] }\end{array}$ & Protein coding & intron & Multiple TSS [10] \\
\hline $\begin{array}{l}\mathrm{miR}-181 \mathrm{c} / 181 \mathrm{~d} \\
\text { chr. } 19\end{array}$ & $\begin{array}{l}\text { NANOS3 } \\
{[22-24]}\end{array}$ & Protein coding & intron & Own TSS [10] \\
\hline $\begin{array}{c}\operatorname{miR}-183 / 96 / 182 \\
\text { chr. } 7\end{array}$ & $\begin{array}{l}\text { MIR96 } \\
{[23,24]}\end{array}$ & Non-coding & intergenic & Own TSS [10] \\
\hline $\begin{array}{l}\operatorname{miR}-191 / 425 \\
\text { chr. } 3\end{array}$ & $\begin{array}{l}\text { NDUFA3 } \\
\text { [16] }\end{array}$ & Protein coding & intron & Host gene TSS [25] \\
\hline $\begin{array}{l}\mathrm{miR}-200 \mathrm{c} / 141 \\
\text { chr. } 12\end{array}$ & $\begin{array}{l}\text { MIR200CHG } \\
\text { [26] }\end{array}$ & Long non-coding & intergenic & Own TSS [27] \\
\hline $\begin{array}{l}\operatorname{miR}-203 a / 203 b \\
\text { chr. } 14\end{array}$ & $\begin{array}{l}\text { MIR203A } \\
{[28]}\end{array}$ & Non-coding & intergenic & Own TSS [10] \\
\hline $\begin{array}{l}\operatorname{miR}-222 / 221 \\
\text { chr. } X\end{array}$ & $\begin{array}{l}\text { MIR222HG } \\
\text { [25] }\end{array}$ & Long non-coding & intergenic & Own TSS [10] \\
\hline $\begin{array}{l}\mathrm{miR}-23 \mathrm{a} / 27 \mathrm{a} / 24-2 \\
\text { chr. } 19\end{array}$ & $\begin{array}{l}\text { MIR23AHG } \\
{[26]}\end{array}$ & Long non-coding & intergenic & Own TSS [29] \\
\hline $\begin{array}{c}\operatorname{miR}-29 b-1 / 29 a \\
\text { chr. } 7\end{array}$ & $\begin{array}{l}\text { LINC-PINT } \\
{[30]}\end{array}$ & Long non-coding & intergenic & Multiple TSS [10] \\
\hline $\begin{array}{c}\mathrm{miR}-301 \mathrm{~b} / \mathrm{miR}-130 \mathrm{~b} \\
\text { chr. } 22\end{array}$ & $\begin{array}{c}\text { PPIL2 } \\
\text { [31] }\end{array}$ & Protein coding & intron & Multiple TSS [10] \\
\hline $\begin{array}{c}\operatorname{miR}-452 / 224 \\
\text { chr. } X\end{array}$ & $\begin{array}{l}\text { GABRE } \\
\text { [9] }\end{array}$ & Protein coding & intron & $\begin{array}{l}\text { Co-expression with the host gene } \\
\text { [17-19] }\end{array}$ \\
\hline
\end{tabular}

Abbreviations-MCM7 (minichromosome maintenance complex component 7), MIR17HG (miR-17-92a-1 cluster host gene), MIR181A1HG (MIR181A1 host gene), NR6A1 (nuclear receptor subfamily 6 group A member 1), NANOS3 (nanos C2HC-type zinc finger 3), NDUFA3 (NADH:ubiquinone oxidoreductase subunit A3), MIR200CHG (MIR200C and MIR141 host gene), MIR222HG (miR222/221 cluster host gene), MIR23AHG (miR-23a/27a/24-2 cluster host gene), LINC-PINT (long intergenic non-protein coding RNA, p53 induced transcript), PPIL2 (peptidylprolyl isomerase like 2), GABRE (gamma-aminobutyric acid type A receptor subunit epsilon). TSS-transcription start site.

Three clusters, miR-106a/363, miR-222/221 and miR-452/224, are located on the $X$ chromosome. Chromosome 7 hosts three clusters, miR-106b/93/25, miR-183/96/182 and miR-29b-1/29a, and two clusters, miR-23a/27a/24-2 and miR-181c/181d, are located on chromosome 19.

An earlier study showed that transcription of intronic miRNAs is regulated by the promoter of their host gene, and intronic miRNA expression is thus frequently correlated with that of the host gene [9]. However, several later studies revealed that co-expression of intronic miRNAs with their host genes may vary according to evolutionary miRNA conservation or localization on the DNA strand. Evolutionarily conserved miRNAs were more frequently co-expressed with their host genes, compared with evolutionarily nonconserved miRNAs [16,21]. Additionally, antisense miRNAs localised on the opposite strand to their host genes were less frequently co-expressed with their host genes, compared with sense miRNAs [21]. Intragenic miRNAs are predominantly independent transcription units, and they have their own transcription regulatory elements [25]. In Table 1, selected miRNA clusters are listed along with a characterization of the transcription start sites (TSS) 
of miRNA genes. Transcription of intronic miRNA genes may be regulated by their host gene's TSS (characterised as TSS-dependent), or intronic miRNA genes may have their own TSS (independent TSS). Co-expression with the host gene was analysed in human CRC tissues (Table 1).

The most miRNA clusters in the human genome contain two to six miRNA members [32]. All clusters included in our study fit within this range. Ten of the selected clusters contain two miRNA members each, three of the selected clusters contain three miRNA members each, and two clusters have six miRNA members.

Transcription factors involved in miRNAs regulation usually also influence the expression of protein-coding genes. However, intergenic and intronic miRNAs seem to be preferentially regulated by different sets of transcription factors [10]. In our study, attention is given to three transcription factors supported by strong experimental evidence, zinc finger E-box binding homeobox 1 (ZEB1), MYC proto-oncogene, bHLH transcription factor (MYC) and p53, which have been validated as regulators of several selected miRNA clusters in human CRC cell lines [33,34]. ZEB1, MYC and p53 mediated regulation of miRNA transcription is described in detail in the discussion.

Epigenetic DNA modifications, such as methylation, are important inhibitory factors of gene expression, and several methylation markers have been proposed as prognostic epigenetic markers for CRC [35]. Epigenetic changes are also involved in the regulation of miRNA expression. In particular, promoter methylation with an inhibitory influence on the expression of clusters miR-200c/141 [36,37] and miR-363 [38] has been proven.

\subsection{Regulation of miRNA Expression by Long Non-Coding RNAs}

RNA transcripts, not translated into proteins, with sequences longer than $200 \mathrm{nu}$ cleotides are commonly classified as long non-coding RNAs (lncRNA), can be divided into several subclasses according to their functions and origins. The most studied groups of lncRNAs are long intergenic ncRNAs (lincRNAs), antisense RNAs (asRNAs), pseudogenes, circular RNAs (circRNAs) and intronic lncRNAs [39].

Mature lncRNAs are folded into complex secondary and tertiary structures with binding domains for interaction with proteins, DNA and other RNA molecules [40]. Interplay between lncRNAs and miRNAs has been observed at several regulatory levels [9,39]. Firstly, lncRNAs may serve as host genes of miRNAs [9]. Analysis of 232 miRNAs revealed that $10 \%$ of analysed miRNAs are located in introns of lncRNAs. Thirty miRNA genes which overlap with exons of non-coding RNAs were also identified [22]. Biogenesis of miRNAs transcribed from lncRNA host genes differs from canonical miRNA biogenesis in several aspects, such as transcription termination or polyadenylation of miRNA gene transcript. In our study, six host genes of selected clusters are also classified as lncRNAs-MIR17HG, MIR181AHG, MIR200CHG, MIR222HG, MIR23AHG and LINC-PINT (Table 1). Another function of lncRNAs is binding to miRNAs with complementary sequences and repressing miRNA-mRNA interaction (competing endogenous RNAs). The regulatory function of lncRNAs contributes significantly to the cancer development and progression and numerous IncRNAs with tumour-promoting or tumour-suppressing functions in colorectal cancer have already been identified [40].

Our analysis revealed 34 lncRNAs validated as sponges for miRNAs from selected clusters in CRC cell lines (Table 2). The most of the detected lncRNAs show an inhibitory influence only with respect to one miRNA in colorectal cancer cells, but our analysis also revealed three lncRNAs that sponge multiple miRNAs or even a whole miRNA cluster. The lncRNA CCAT1 sponges miRNAs from two homolog clusters, miR-181a-1/181b-1 and miR-181a-2/181b-2 [41,42]. The lncRNA ATB sponges the expression of both miRNAs from cluster miR-200c/141 [43,44].

Nearly one third of detected lncRNAs are classified as asRNAs (Table 2). Antisense RNAs are located on the opposite strand of a protein-coding DNA or protein non-coding genes and are involved in the modulation of miRNA-mediated inhibition of expression of a gene in their close proximity [45]; e.g., ZEB1 antisense RNA 1 (asRNA ZEB1-AS1) 
influences the expression of the transcription factor ZEB1 by sponging miR-141-3p, which inhibits ZEB1 expression [46,47].

Table 2. List of lncRNAs and circRNAs sponging up-regulated miRNA clusters in human CRC cell lines.

\begin{tabular}{|c|c|c|c|}
\hline miRNA Cluster & Sponging ncRNA & ncRNA Class & Reference \\
\hline miR-183/96/182 & AGER-1 & intronic ncRNA & [48] \\
\hline $\mathrm{miR-203a/203b}$ & BANCR & lincRNA & [49] \\
\hline $\mathrm{miR}-106 \mathrm{~b} / 93 / 25$ & CA3-AS1 & antisense RNA & {$[50]$} \\
\hline $\begin{array}{l}\operatorname{miR}-181 a-1 / 181 b-1 \\
\text { miR-181a-2/181b-2 }\end{array}$ & CCAT1 & lincRNA & {$[41,42]$} \\
\hline $\operatorname{miR}-106 b / 93 / 25$ & circ_000984 (CDK6) & circRNA & [51] \\
\hline miR-183/96/182 & circ_0026344 (ACVRL1) & circRNA & [52] \\
\hline miR-106b/93/25 & circ_0055625 (DUSP2) & $\operatorname{circRNA}$ & [53] \\
\hline $\mathrm{miR-203a/203b}$ & circ_0079993 (POLR2J4) & circRNA & [54] \\
\hline $\mathrm{miR}-106 \mathrm{~b} / 93 / 25$ & circ-SMARCA5 (SMARCA5) & circRNA & [55] \\
\hline $\begin{array}{l}\operatorname{miR}-181 a-1 / 181 b-1 \\
\operatorname{miR}-181 a-2 / 181 b-2\end{array}$ & CRNDE & antisense RNA & [56] \\
\hline miR-106a/18b/20b/19b-2/92a-2/363 & FARSA-AS1 & antisense RNA & [57] \\
\hline $\operatorname{miR}-203 a / 203 b$ & FBXL19-AS & antisense RNA & [58] \\
\hline $\mathrm{miR}-106 \mathrm{a} / \mathbf{1 8 b} / 20 \mathrm{~b} / 19 \mathrm{~b}-2 / 92 \mathrm{a}-2 / 363$ & FBXW7 & lincRNA & [59] \\
\hline miR-17/18a/19a/20a/19b-1/92a-1 & FENDRR & lincRNA & {$[60]$} \\
\hline miR-106b/93/25 & FOXD2-AS1 & antisense RNA & [61] \\
\hline $\operatorname{miR}-183 / 96 / 182$ & GAS5 & antisense RNA & [62] \\
\hline $\begin{array}{l}\mathrm{miR}-200 \mathrm{c} / 141 \\
\mathrm{miR}-29 \mathrm{~b}-1 / 29 \mathrm{a}\end{array}$ & H19 & lincRNA & {$[63,64]$} \\
\hline $\operatorname{miR}-17 / 18 a / 19 a / 20 a / 19 b-1 / 92 a-1$ & HAND2-AS1 & antisense RNA & [65] \\
\hline $\begin{array}{l}\mathrm{miR}-106 \mathrm{~b} / 93 / 25 \\
\mathrm{miR}-203 \mathrm{a} / 203 \mathrm{~b}\end{array}$ & HOTAIR & antisense RNA & {$[66,67]$} \\
\hline $\operatorname{miR}-17 / 18 a / 19 a / 20 a / 19 b-1 / 92 a-1$ & HOTAIRM1 & lincRNA & [68] \\
\hline $\operatorname{miR}-29 b-1 / 29 a$ & LIFR-AS1 & antisense RNA & [69] \\
\hline $\mathrm{miR}-106 \mathrm{~b} / 93 / 25$ & LINC00858 & lincRNA & [70] \\
\hline $\mathrm{miR}-106 \mathrm{~b} / 93 / 25$ & LINC01567 & lincRNA & [71] \\
\hline $\operatorname{miR}-203 a / 203 b$ & LINC02595 & lincRNA & [72] \\
\hline $\operatorname{miR}-29 b-1 / 29 a$ & LINC-PINT-variant D & antisense RNA & [29] \\
\hline $\operatorname{miR}-200 \mathrm{c} / 141$ & lncRNA ATB & pseudogene & {$[43,44]$} \\
\hline $\begin{array}{c}\operatorname{miR}-106 b / 93 / 25 \\
\mathrm{miR}-106 \mathrm{a} / 18 \mathrm{~b} / \mathbf{2 0 b} / 19 \mathrm{~b}-2 / 92 \mathrm{a}-2 / 363\end{array}$ & MALAT1 & lincRNA & {$[73-75]$} \\
\hline $\mathrm{miR}-\mathbf{2 0 0 c / 1 4 1}$ & MEG3 & lincRNA & [76] \\
\hline $\mathrm{miR-203a/203b}$ & NORAD & lincRNA & {$[77]$} \\
\hline miR-200c/141 & SNHG15 & intronic ncRNA & [78] \\
\hline $\begin{array}{c}\operatorname{miR}-17 / \mathbf{1 8 a} / 19 a / 20 a / 19 b-1 / 92 a-1 \\
\text { miR-183/96/182 }\end{array}$ & UCA1 & lincRNA & [79] \\
\hline $\operatorname{miR}-183 / 96 / 182$ & XIRP2-AS1 & antisense RNA & [80] \\
\hline $\begin{array}{c}\mathrm{miR}-106 \mathrm{~b} / \mathbf{9 3} / 25 \\
\mathrm{miR}-200 \mathrm{c} / \mathbf{1 4 1}\end{array}$ & XIST & lincRNA & [81] \\
\hline $\begin{array}{l}\operatorname{miR-181a-1} / 181 b-1 \\
\operatorname{miR}-181 a-2 / 181 b-2\end{array}$ & ZEB1-AS1 & antisense RNA & {$[47,82]$} \\
\hline
\end{tabular}

In the first column referring to miRNA clusters, the targeted miRNA is emboldened. Host genes of circular RNAs (circRNAs) are given in parentheses-CircBase [83]. lincRNAs—long intergenic non-coding RNAs.

Intronic lncRNAs may also be involved in the regulation of the expression of genes located in their proximity via interactions with miRNA, e.g., IncRNA AGER-1, located in the intron of the AGER-coding gene (advanced glycosylation end-product specific receptor), inhibits interaction of miR-182 with AGER mRNA by miRNA sponging [48]. Newly identified lncRNA generated as a splicing variant of gene LINC-PINT was shown to sponge a member of the miR-29b-1/29a cluster, miR-29b, located in the same host gene in CRC cells [29]. 


\section{4. miRNA Families}

A miRNA family includes homolog miRNAs with identical seed sequences. A seed sequence is a region located in the $5^{\prime}$ end of mature miRNA with a length of seven to eight nucleotides. Binding of miRNA to its target mRNA relies predominantly on the miRNA seed sequence, but the $3^{\prime}$ and central regions of the miRNA sequence are also of importance in mRNA recognition [84]. Thus, the inhibitory potential of miRNAs from the same family with identical seed sequences may differ depending on RNA context in the proximity of seed sequence [85].

miRNA clusters may contain miRNAs from different families and, vice versa, miRNAs from one family can be located in different clusters. More than half of all human miRNA clusters contain homolog miRNAs (from one family) [86]. This distribution was also observed among the 15 clusters analysed in this study, where seven clusters contained only miRNAs classified in one family (Table 3). Evolutionary analysis showed that miRNA clusters with homolog miRNA seed sequences were mainly created by gene duplication [32]. On the other hand, five clusters contained miRNAs only from distinct families.

Table 3. Table of miRNA families of selected miRNA clusters and their seed sequences.

\begin{tabular}{|c|c|c|}
\hline Cluster & Family & Seed Sequence \\
\hline $\operatorname{miR}-301 b / 130 b$ & miR-130-3p/301-3p/454-3p & AGUGCA \\
\hline $\mathrm{miR}-200 \mathrm{c} / 141$ & $\operatorname{miR}-141-3 p / 200 a-3 p$ & AACACUG \\
\hline $\operatorname{miR}-106 a / 18 b / 20 b / 19 b-2 / 92 a-2 / 363$ & & \\
\hline miR-106b/93/25 & miR-17-5p/20-5p/93-5p/106-5p/519-3p & AAAGUGC \\
\hline $\operatorname{miR-17/18a/19a/20a/19b-1/92a-1~}$ & & \\
\hline $\begin{array}{c}\text { miR-181a-1/181b-1;181a-2/181b-2 } \\
\text { miR-181c/181d }\end{array}$ & miR-181-5p & ACAUUCA \\
\hline miR-183/96/182 & miR-182-5p & UUGGCAA \\
\hline $\operatorname{miR}-183 / 96 / 182$ & miR-183-5p & AUGGCAC \\
\hline $\begin{array}{c}\operatorname{miR}-106 a / 18 b / 20 b / 19 b-2 / 92 a-2 / 363 \\
\operatorname{miR}-17 / \mathbf{1 8 a} / 19 a / 20 a / 19 b-1 / 92 a-1\end{array}$ & $\operatorname{miR}-18-5 p$ & AAGGUGC \\
\hline miR-191/425 & miR-191-5p & AACGGAA \\
\hline $\begin{array}{c}\operatorname{miR}-17 / 18 a / 19 a / 20 a / 19 b-1 / 92 a-1 \\
\operatorname{miR}-106 a / 18 b / 20 b / 19 b-2 / 92 a-2 / 363\end{array}$ & $\operatorname{miR}-19-3 p$ & GUGCAAA \\
\hline $\operatorname{miR}-203 a / 203 b$ & miR-203a-3p.2 & UGAAAUG \\
\hline $\mathrm{miR}-203 \mathrm{a} / 203 \mathrm{~b}$ & $\operatorname{miR}-203 b-3 p$ & UGAACUG \\
\hline $\operatorname{miR}-222 / 221$ & $\operatorname{miR}-221-3 p / 222-3 p$ & GCUACAU \\
\hline $\operatorname{miR}-452 / 224$ & miR-224-5p & AAGUCAC \\
\hline $\operatorname{miR}-23 a / 27 a / 24-2$ & $\operatorname{miR}-23-3 p$ & UCACAUU \\
\hline $\begin{array}{l}\operatorname{miR}-23 a / 27 a / 24-2 \\
\operatorname{miR}-106 b / 93 / 25\end{array}$ & $\operatorname{miR}-24-3 p$ & GGCUCAG \\
\hline $\begin{array}{c}\operatorname{miR}-106 a / 18 b / 20 b / 19 b-2 / 92 a-2 / 363 \\
\operatorname{miR}-17 / 18 a / 19 a / 20 a / 19 b-1 / 92 a-1\end{array}$ & $\operatorname{miR}-25-3 p / 32-5 p / 92-3 p / 363-3 p / 367-3 p$ & AUUGCAC \\
\hline $\mathrm{miR}-23 \mathrm{a} / 27 \mathrm{a} / 24-2$ & $\operatorname{miR}-27-3 p$ & UCACAGU \\
\hline $\operatorname{miR}-29 b-1 / 29 a$ & $\operatorname{miR}-29-3 p$ & AGCACCA \\
\hline miR-191/425 & $\operatorname{miR}-425-5 p$ & AUGACAC \\
\hline $\operatorname{miR}-452 / 224$ & miR-452-5p/892-3p & ACUGUUU \\
\hline $\operatorname{miR}-183 / 96 / 182$ & miR-96-5p/1271-5p & UUGGCAC \\
\hline
\end{tabular}

In the first column are miRNA clusters with emboldened miRNAs which are included in the miRNA family in the second column. The third column contains the sequence of the seed region common to the miRNA family. Data were extracted from TargetScan [87].

The up-regulated miRNA clusters selected for our study contain miRNAs from 21 miRNA families. A substantial number of the selected miRNAs belong to the family miR-17-5p/20-5p/93-5p/106-5p/519-3p, which contains six miRNAs located in three homolog clusters: miR-106a/363, miR-106b/93/25 and miR-17/92a-1 (Table 3).

Nearly $20 \%$ of miRNA clusters in the human genome contain mature miRNAs that can be generated from more than one pre-miRNA [86]. The miRNA clusters analysed in our study contain 41 pre-miRNAs, which are processed into 37 mature miRNAs. Four mature miRNAs are processed from two precursors each, which are located in several 
clusters. Mature miR-181a and miR-181b are processed from their precursor miRNAs included in two clusters: miR-181a-1/181b-1 and miR-181a-2/181b-2. Similarly, mature miR-92a and miR-19b are processed from precursors included in two miRNA clusters: miR-17/92a-1 and miR-106a/363. Mature miR-24 is also processed from two pre-miRNAs from two different clusters, but we selected for this study only cluster miR-23a/27a/24-2. Its homologue cluster miR-23b / 27b / 24-1 did not fit our criteria for miRNA cluster selection. Similarly, only one precursor for miR-29b from the miR-29b-1/29a cluster was included in the analyses, and the miR-29b-2/29c cluster was omitted.

\subsection{Expression of miRNA Clusters in Tissues, the Circulation and Stool of Patients with CRC}

Up-regulation of selected miRNA expression in tissues and the circulation of CRC patients was verified by a set of studies obtained by a search in the PubMed database. The expression of 14 miRNA clusters was predominantly increased in CRC tumour tissues, compared with adjacent tissues. Nearly all members of the miR-106a/363 cluster were identified in the majority of the studies as being up-regulated in CRC tissue (Supplementary Material S2).

Tumour biopsy is an invasive procedure, and in many instances, it is difficult to obtain a sufficient amount of tissue for genome profiling and gene expression analysis. Liquid biopsy is a new diagnostic concept based on analyses of cell-free DNA, RNA and other molecules in the circulation [88]. miRNAs in the circulation are encapsulated in exosomes and microvesicles. Extracellular vesicles secreted by cells could be classified according to their size and biogenesis into six categories: exosomes, microvesicles, ectosomes, large oncosomes, exosome-like vesicles and apoptotic vesicles [89]. Extracellular vesicles containing various classes of bioactive molecules-DNA, RNA, proteins and lipids-seem to be an important tool for homotypic and heterotypic communication of cells in tumours [90]. However, there is also a significant amount of free circulating miRNA, which is associated with the Argonaut2 protein [91].

The release and uptake of exosomes is regulated by complex mechanisms, which may be modified by the tumour microenvironment; e.g., uptake of exosomes is regulated by $\mathrm{pH}$ as lower $\mathrm{pH}$ induces an increase in the uptake and release of exosomes. However, there are indications that at least some of the miRNAs in the circulation originate in white blood cells, and thus, the levels of miRNAs in the plasma may vary according to changes in the leukocyte count [92].

Tumour cells actively reprogram stromal cells and cells of the immune system through exosome secretion $[93,94]$. Genes and miRNAs in exosomes may modify the growth or invasiveness of recipient cells [93]. The influence of microvesicles derived from CRC cell lines on monocytes seems to depend on the degree of monocyte differentiation [95].

Most of the selected miRNA clusters showed up-regulated expression in the plasma and serum, compared with the control group. The expression of all miRNAs from the clusters miR-17/92a-1, miR-181a-1/181b-1， miR-181a-2/181b-2, miR-181c/181d, miR-183/96/182, miR-191/425, miR-200c/141, miR-203a/203b, miR-222/221 and $\mathrm{miR}-301 \mathrm{~b} / 130 \mathrm{~b}$ was predominantly increased in plasma, serum or isolated exosomes of patients with CRC, compared with the control group. Information about the up- or downregulation of the analysed miRNA clusters in the circulation is given in Supplementary Material S2.

Surgical removal of the tumour led to decreased plasma expression of miR-106a-5p [96], miR-18a, miR-17-3p and miR-92a [97] from two homolog clusters: miR-17/92a-1 and $\mathrm{miR}-106 \mathrm{a} / 363$. Expression of miR-23a and miR-20a in plasma was lower after radical surgical removal of the tumour [98] and expression of miR-29a and miR-92a decreased in post-operative plasma [99]. Plasma miR-182 levels decreased one month after radical liver metastasectomy, compared with that in preoperative plasma [100]. Expression of miR-29b-3p was decreased in postoperative plasma, compared with that in preoperative plasma, and after dividing patients by gender, this difference remained significant in both groups [101]. After surgical removal of the tumour, the expression of miR-23a was de- 
creased in serum exosomes [102] and plasma extracellular vesicles [103] compared with preoperative levels. Similarly, tumour resection led to decreased expression of miR-106a and miR-17-3p in post-operative serum samples, compared with preoperative serum [104]. Expression of miR-182 was decreased in postoperative serum, compared with serum collected before operation. However, in patients with postoperative CRC recurrence, re-elevation of miR-182 serum levels was observed [105].

The abovementioned evidence implicates an association between miRNA levels in the circulation and pre- and post-surgery levels of miRNA in the colorectum. Surgical removal of the tumour and/or metastases frequently results in decreases in associated miRNAs in the circulation. Changes in miRNA levels in the plasma were more prominent after radical surgical removal of the tumour, compared with palliative tumour removal (liver metastases were not removed) [98].

Current widely used methods for early diagnosis of CRC include the faecal occult blood test (FOBT) and the faecal immunochemical test [106]. Isolation of DNA from colonocytes in faeces enabled DNA analyses, such as analyses of gene mutations and epigenetic changes related to CRC development. Analyses of the expression of genes and other non-coding RNAs from stool is also a potential tool for non-invasive CRC diagnosis [107-109]. Widely used non-invasive screening methods include the faecal blood test, detecting the presence of haemoglobin in stool, the faecal immunochemical test and a test based on DNA isolated from colonocytes in faeces $[106,107,110]$.

miRNAs are also detectable in stool samples, and screening of faecal miRNA expression may be a useful tool for the diagnosis of intestinal diseases. The stability of faecal miRNAs depends on their origin, as miRNAs in colonocytes and exosomes are more resistant to degradation by RNase than free miRNAs [111]. Analysis of human CRC tumours and adjacent normal mucosa specimens showed that colonocytes in the mucocellular layer over CRC tumours were more abundant than those in the mucocellular layer over the normal mucosa [112]. The levels of all members of the miR-17-92a-1 cluster were increased in the stools of CRC patients, compared with controls. On the other hand, the levels of members of the miR-29b/miR-29a cluster were decreased (Table 4).

Table 4. Changes in miRNA expression in the stools of patients with CRC, compared with controls.

\begin{tabular}{|c|c|c|}
\hline Cluster & miRNA & Levels in Stool \\
\hline \multirow{3}{*}{ miR-106a/18b/20b/19b-2/92a-2/363 } & miR-106a & $\uparrow[107,113]$ \\
\hline & $\operatorname{miR}-19 b$ & $\uparrow[114,115]$ \\
\hline & miR-92a & $\uparrow[107,114-116]$ \\
\hline \multirow{6}{*}{ miR-17/18a/19a/20a/19b-1/92a-1 } & miR-17 & $\uparrow[107,115,116]$ \\
\hline & miR-18a & $\uparrow[115,117]$ \\
\hline & miR-19a & $\uparrow[115]$ \\
\hline & miR-20a & $\uparrow[107,114,115]$ \\
\hline & miR-19b & $\uparrow[114,115]$ \\
\hline & miR-92a & $\uparrow[107,114-116]$ \\
\hline \multirow{2}{*}{ miR-183/96/182 } & miR-183 & $\uparrow[107]$ \\
\hline & miR-96 & $\uparrow[107]$ \\
\hline \multirow{2}{*}{$\operatorname{miR}-222 / 221$} & miR-222 & $\downarrow[107]$ \\
\hline & miR-221 & $\uparrow[117]$ \\
\hline \multirow{2}{*}{$\operatorname{miR}-29 b / 29 a$} & miR-29b & $\downarrow[117]$ \\
\hline & miR-29a & $\downarrow[118]$ \\
\hline $\mathrm{miR}-301 \mathrm{~b} / 130 \mathrm{~b}$ & miR-130b & $\uparrow[119]$ \\
\hline $\mathrm{miR}-452 / 224$ & miR-224 & $\downarrow[118]$ \\
\hline
\end{tabular}

Levels of miRNAs in stool of patients with CRC were compared to samples from healthy donors. $\uparrow$ depict increased levels of miRNA in stool of patients with CRC compared to controls, $\downarrow$ depicts decreased levels of miRNA. 
miRNAs from the homolog clusters miR-17/92a-1 and miR-106a/363 were proposed as potential biomarkers in stool samples. The levels of miR-18a-5p, miR-19a-3p, miR-19b-3p, miR-20a-5p, miR-92a-3p and miR-106a were decreased in stool samples collected 12-30 months after surgery, compared with preoperative samples. Similarly, the levels of miR-20a-5p and miR-141 in postoperative samples were normalised to those in healthy control samples. On the other hand, the levels of miR-92a-3p remained higher compared to control [114].

Other biological substances that can be collected using non-invasive methods and may be used as a source of several types of biomarkers for CRC diagnosis include saliva, urine and colonic mucus [109]. A study from 2019 revealed that the expression of miR-29a-3p was increased in the saliva of patients with CRC compared with controls. The levels of miR-29a-3p in saliva also showed sex-dependent differences, as expression in the saliva of men was increased, compared with that in women [120].

\subsection{Association of miRNA Clusters Expression with Clinicopathological Characteristics}

Detection of CRC in its early stages is associated with a better prognosis for patients. The initial stages of CRC are, in most cases, asymptomatic; therefore, numerous screening programs are focused on the early detection of CRC [110]. Strategies for CRC screening programs differ in terms of the age at which screening begins, frequency of screening and methods used. These parameters can be optimised to increase the sensitivity and efficiency of screening. The prognosis of patients with CRC also seems to depend on the length of the diagnostic interval between the appearance of the first symptoms and CRC diagnosis [121], as well as the morphological types of polyps presented in the colorectum [122].

Current screening methods have several limitations due to their low specificity and sensitivity, invasiveness, or high cost. There are several promising markers, including detection of mutations, proteins and mRNA, which are commercially available or in the testing stage [106,110]. In clinical practice, there are few miRNA-based diagnostic tools [4]. Diagnostic biomarkers for CRC could be classified according to the examined specimen into tissue, circulation and faecal markers [106,110].

Colonoscopy and sigmoidoscopy are commonly used invasive methods to detect the presence of polyps in the colorectum and to resect samples for biopsy. Several genetic tests for evaluating the diagnosis and prognosis of CRC from tissue samples beside histopathological and immunochemical analyses are currently used in clinical practice $[106,110,123]$. The microsatellite instability (MSI) test is based on a measurement of a panel of several markers including BAT25, BAT26, D5S346, D2S123 and D17S250. The indicator of MSI is the presence of mutation in genes involved in mismatch repair, e.g., hMLH1 and hMSH2 [110,123]. Other gene mutations showing a strong effect on CRC development include mutations in the genes KRAS, BRAF and APC [110].

Recently, circulation markers, e.g., glycoproteins CEA (carcinoembryonic antigen) and CA19-9 (cancer antigen 19-9) are widely used for CRC diagnosis [124-126] but miRNAs in the circulation are also promising markers for CRC diagnosis. miRNAs in vesicles were reported to be resistant to degradation by RNase A, and their levels stayed stable during $24 \mathrm{~h}$ of incubation at room temperature or during several freeze-thaw cycles $[127,128]$.

A panel of several dysregulated miRNAs in the circulation seems to be a more efficient diagnostic and prognostic factor than a single miRNA. Previous studies showed that a panel of selected miRNAs showed higher sensitivity as a prognostic marker for early CRC diagnosis, compared with CEA. However, the highest sensitivity was displayed when a combination of CEA and a miRNA panel were used together [98,102,124,129].

The up-regulated miRNA clusters selected for our study also showed associations with clinicopathological characteristics, such as TNM stage, tumour size, metastasis and low differentiation. The presence of distant or lymph node metastasis predominantly positively correlated with up-regulation of all miRNAs from clusters miR-17/92a-1, miR-183/96/182, miR-191/425 and miR-200c/141. Advanced TNM stage was associated with increased ex- 
pression of several miRNAs from clusters miR-17/92a-1, miR-106a/93/25, miR-183/96/182 and miR-200c/141 in serum or tumour tissue (Supplementary Material S3).

miRNAs are a promising prognostic factor for predicting patient survival and disease recurrence. Up-regulation of the majority of miRNAs from clusters miR-17/92a-1, miR-106b/363, miR-181-1/182-1, miR-181-2/182-2 and miR-183/96/182 in tumour tissue or the circulation was associated with shorter patient survival and increased disease recurrence. The expression of both members of the miR-222/221 cluster positively correlated with disease recurrence. miRNAs from cluster miR-106b/93/25 were differentially associated with patient prognosis. Increased expression of miR-106b and miR-93 in tumour tissue was associated with improved survival and a lower incidence of relapse, whereas up-regulation of miR-25 in tumour tissue was associated with worse survival (Table 5).

Table 5. miRNAs associated with worse survival or disease recurrence/relapse.




Table 5. Cont.

\begin{tabular}{|c|c|c|c|}
\hline miRNA Cluster & miRNA & $\begin{array}{c}\text { Association with Worse } \\
\text { Survival }\end{array}$ & $\begin{array}{l}\text { Association with Disease } \\
\text { Reccurence/Relapse }\end{array}$ \\
\hline $\operatorname{miR}-23 a / 27 a / 24-2$ & $\begin{array}{l}\text { miR-23a } \\
\text { miR-27a } \\
\text { miR-24 }\end{array}$ & $\begin{array}{c}\uparrow \mathrm{P}[98] \\
\uparrow \mathrm{TU}[183-186] \\
\uparrow \mathrm{TU}[187] \\
\downarrow \mathrm{TU}[188]\end{array}$ & 个 TU [187] \\
\hline $\mathrm{miR}-29 \mathrm{~b} / 29 \mathrm{a}$ & $\begin{array}{l}\operatorname{miR}-29 b \\
\operatorname{miR}-29 a\end{array}$ & $\begin{array}{c}\uparrow \mathrm{TU}[189] \\
\downarrow \mathrm{P}[143] ; \mathrm{TU} \text { [64] } \\
\uparrow \mathrm{TU}[190] \\
\downarrow \text { TU [191] }\end{array}$ & $\begin{array}{l}\uparrow \mathrm{P}[192] \\
\downarrow \mathrm{TU}[193]\end{array}$ \\
\hline $\mathrm{miR}-301 \mathrm{~b} / 130 \mathrm{~b}$ & miR-130b & 个 TU [194] & \\
\hline $\operatorname{miR}-452 / 224$ & $\begin{array}{l}\operatorname{miR}-452 \\
\operatorname{miR}-224\end{array}$ & $\begin{array}{c}\uparrow \mathrm{TU}[195] \\
\downarrow \mathrm{TU}[196] \\
\uparrow \mathrm{TU}[197,198] \\
\downarrow \text { TU }[182]\end{array}$ & 个 TU [197] \\
\hline
\end{tabular}

$\uparrow$ indicates increased expression/level of miRNA, $\downarrow$ decreased expression/level associated with worse survival or disease recurrence. The source for the measurement of miRNA expression is emboldened-TU (tumour tissue); P (plasma); S (serum); AT (adjacent tissue); LM (liver metastasis).

\subsection{Association of miRNA Cluster Expression with Response to Chemotherapy}

The development of colorectal tumours is usually a slow, multi-step process accompanied by histological, morphological, and genetic changes that accumulate over time. Colorectal tumours develop from benign precancerous polyps, predominantly from adenomas and sessile serrated polyps [199]. The most common genetic changes associated with the early stages of CRC development are chromosomal and microsatellite instabilities, which are associated with drug resistance. Chromosomal instability results mostly from defects in chromosomal segregation, decreased telomere stability and insufficient DNA damage repair [200]. Microsatellites are short DNA motifs which are distributed throughout the genome. Repetitive microsatellite DNA sequences are more resistant to errors in replication, thus the accumulation of mistakes in microsatellites points to a deficit in the mis-match repair system (MMR), which rectifies mismatches in the DNA sequence during replication [201]. Chromosomal and microsatellite instabilities are closely related to an increased number of gene mutations [200]. Within the selected up-regulated clusters, the expression of miR-221, miR-224, miR-181b and miR-92 in CRC tissue was associated with microsatellite instability $[198,202]$. Mutations of key regulatory genes such as thymidylate synthase or components of the p53 pathway may also lead to the development of resistance to chemotherapy $[108,203]$.

The most commonly used chemotherapeutics for CRC treatment are 5-fluorouracil (5-FU) and oxaliplatin. 5-FU is a uracil analogue, which, after intracellular metabolization to several active metabolites, inhibits RNA synthesis [204]. Platinum-containing drugs, e.g., oxaliplatin, cisplatin and carboplatin, bind preferentially to DNA molecules and inhibit DNA replication and transcription through the formation of DNA adducts [205].

Several miRNAs from up-regulated clusters are involved in signalling pathways associated with sensitivity to chemotherapy and have the potential to become a tool in CRC treatment [206]. Higher expression of miR-27a, miR-20b and miR-106a-5p in CRC tissue was associated with a worse response to treatment with 5-FU [207-209]. The expression of miR-17-5p, miR-19b, miR-20a and miR-93 from the miR-17/92a- 1 cluster and its paralogous cluster miR-106b/93/25 was increased in CRC tumours resistant to 5-FU-based adjuvant therapy compared with chemo-sensitive tumours. Increased expression of miR-17-3p in the tumour tissues of non-responsive patients was correlated with shorter survival [150]. Additionally, high expression of miR-92a-3p in tumour tissues was associated with worse response to neoadjuvant therapy based on 5-FU [210].

Two miRNAs from the miR-17/92a-1 cluster, miR-20a [211] and miR-19a [212] were determined as serum biomarkers for non-responsiveness to FOLFOX therapy (combined ox- 
aliplatin and 5-FU treatment). High expression of miR-17-3p and miR-106a in the serum of patients with stage II and III tumours treated with adjuvant chemotherapy was associated with worse therapeutic outcomes [104]. Increased expression of miR-96-5p in serum exosomes was revealed as a potential predictive biomarker for chemoresistance [213]. miR-106a and miR-130b were validated as plasma biomarkers for the response to 5-FU/oxaliplatin therapy, and increased expression of these miRNAs was associated with a worse response to therapy [214]. Treatment of CRC patients with 5-FU chemotherapy led to increased expression of miR-23a-3p in tumour tissues, compared with untreated tumour tissues [215].

\subsection{Target Genes of miRNA Clusters}

miRNA functions in CRC development are mediated via target genes and key pathways regulating cell proliferation and migration, such as the Wnt/ $\beta$-catenin, PI3K/Akt/mTOR, TGF- $B$ (transforming growth factor beta) and EGFR (epidermal growth factor receptor) signalling pathways $[216,217]$. Deregulated miRNAs in CRC tissue could be classified as oncogenic miRNAs (oncomiRs), promoting tumour development, metastasis or resistance to therapy or tumour-suppressive miRNAs with the opposite effects [218].

Based on recent experimental evidence from studies using CRC cell lines, 181 genes were confirmed as target genes of miRNAs from selected up-regulated clusters. Approximately one sixth of these genes (33) were targeted by two or more miRNAs. An oncogenic or tumour suppressive role in CRC was attributed to target genes based on experimental evidence (Table 6 and Supplementary Material S4).

Table 6. List of target genes of up-regulated miRNA clusters.

\begin{tabular}{|c|c|c|}
\hline Cluster & miRNA & Target Genes \\
\hline \multirow{8}{*}{$\operatorname{miR}-106 a / 18 b / 20 b / 19 b-2 / 92 a-2 / 363$} & miR-106a-5p & ATG7; AMER1; DUSP2; FOXQ1; GABBR1; TGFBR2 \\
\hline & miR-106a-3p & PTEN \\
\hline & $\operatorname{miR}-18 b-5 p$ & CDKN2B; SOX9 \\
\hline & $\operatorname{miR}-20 b-5 p$ & ADAM9; GABBR1; POU5F1 \\
\hline & miR-19b-3p & SMAD4 \\
\hline & $\operatorname{miR}-92 a-5 p$ & AQP8 \\
\hline & $\operatorname{miR}-92 a-3 p$ & $\begin{array}{c}\text { BCL2L11; DDK3; FBXW7; GSK3 } \beta ; \text { KLF4; MOAP1; NF2; } \\
\text { RBM4; RECK; SMAD7 }\end{array}$ \\
\hline & miR-363-3p & EZH2; GATA6; SOX4; SPHK2 \\
\hline \multirow{6}{*}{$\mathrm{miR}-106 \mathrm{~b} / 25 / 93$} & miR-106b-5p & $\begin{array}{c}\text { ATG16L1; CTSA; DLC1; GABBR1; ITGB8; CDKN1A; PLK3; } \\
\text { PRRX1; PTEN; SLAIN2; TRIM8 }\end{array}$ \\
\hline & $\operatorname{miR}-10 b-3 p$ & DLC1 \\
\hline & $\operatorname{miR}-25-5 p$ & NEDD9; PRKCZ \\
\hline & $\operatorname{miR}-25-3 p$ & ANGPTL8; ATXN3; MCU; SEMA4C; SMAD7 \\
\hline & miR-93-5p & $\begin{array}{c}\text { ATG12; ATG16L1; CCND1; CD274; CTNNB1; FOXA1; } \\
\text { HIF1A; MYC; PTEN; SMAD7 }\end{array}$ \\
\hline & $\operatorname{miR}-93-3 p$ & ARID4B \\
\hline \multirow{8}{*}{$\operatorname{miR}-17 / 18 a / 19 a / 20 a / 19 b-1 / 92 a-1$} & $\operatorname{miR}-17-5 p$ & $\begin{array}{c}\text { BTG3; CLU; CYP7B1; GABBR1; NCOA3; PTEN; RBL2; } \\
\text { RND3; SIK1 TGFBR2; TRIM8; VIM }\end{array}$ \\
\hline & $\operatorname{miR}-17-3 p$ & F2RL3 \\
\hline & miR-18a-5p & $\begin{array}{c}\text { ATM; CCND1; CDC42; CDK19; HIF1A; HNRNPA1; ING4; } \\
\text { NEDD9; PIAS3; SMAD4; TBPL1 }\end{array}$ \\
\hline & miR-19a-3p & $\begin{array}{l}\text { FOXF2; KRAS; PTEN; TF; TGFBR2; TGM2; THBS1; TIA1; } \\
\text { TNFAIP3 }\end{array}$ \\
\hline & miR-20a-5p & $\begin{array}{c}\text { AMER1; ATG5; BID; BNIP2; CDKN1A; CXCL8; FOXJ2; } \\
\text { GABBR1; MAP3K5; MICA; PDCD4; RB1CC1; SMAD4; } \\
\text { TGFBR2; VEGFA }\end{array}$ \\
\hline & miR-19b-3p & SMAD4 \\
\hline & $\operatorname{miR}-92 a-5 p$ & AQP8 \\
\hline & miR-92a-3p & $\begin{array}{c}\text { BCL2L11; DDK3; FBXW7; GSK3 } \beta ; \text { KLF4; MOAP1; NF2; } \\
\text { RBM4; RECK; SMAD7; PTEN }\end{array}$ \\
\hline
\end{tabular}


Table 6. Cont.

\begin{tabular}{|c|c|c|}
\hline Cluster & miRNA & Target Genes \\
\hline \multirow{2}{*}{ miR-181a-1/181b-1miR-181a-2/181b-2 } & $\operatorname{miR}-181 a-5 p$ & $\begin{array}{c}\text { CTNNB1; E2F5; MMP14; PLAG1; PTEN; SRCIN1; STAT1; } \\
\text { TCF4; WIF1 }\end{array}$ \\
\hline & $\operatorname{miR}-181 b-5 p$ & PDCD4; PIAS3; RASSF1; TUSC3 \\
\hline miR-181c/181d & miR-181d-5p & PEAK1; FBXL3; CRY2 \\
\hline \multirow{4}{*}{$\operatorname{miR}-183 / 96 / 182$} & miR-183-5p & ABCA1; AFDN; AKAP12; ATG5; RCN2; UVRAG \\
\hline & miR-96-5p & CCND1; FOXO1; FOXO3a; GPC1; KRAS; TP53INP1; TPM1 \\
\hline & miR-96-3p & RECK \\
\hline & $\operatorname{miR}-182-5 p$ & $\begin{array}{c}\text { AGER; DAB2IP; FBXW7; FOXF2; FOXO1; FOXO3a; MTDH; } \\
\text { MYC; SATB2; ST6GALNAC2; THBS1 }\end{array}$ \\
\hline \multirow{2}{*}{$\operatorname{miR}-191 / 425$} & miR-191-5p & С/ЕВР $\beta ;$ TIMP3 \\
\hline & $\operatorname{miR}-425-5 \mathrm{p}$ & CTNND1; PDCD10 \\
\hline \multirow{4}{*}{$\mathrm{miR}-200 \mathrm{c} / 141$} & miR-200c-3p & BMI1; CDK2; ETS1; FLT1; KLF14; SOX2; VLDLR; ZEB1 \\
\hline & $\operatorname{miR}-200 c-5 p$ & PRICKLE2 \\
\hline & miR-141-3p & CCND2; DLC1; EGFR; GEMIN2; MAP2K4; MAP4K4; \\
\hline & & 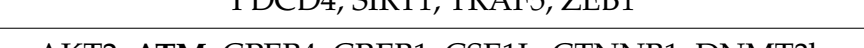 \\
\hline \multirow[t]{2}{*}{$\mathrm{miR}-203 \mathrm{a} / 203 \mathrm{~b}$} & miR-203a-3p & $\begin{array}{c}\text { AKT2; ATM; CPEB4; CREB1; CSE1L; CTNNB1; DNMT3b; } \\
\text { EIF5A2; GATA6; NEDD9; PDE4D; RNF6; ROBO1; SIK2; TCF4; } \\
\text { THBS2; TLE5; TYMS; KLK6 }\end{array}$ \\
\hline & $\operatorname{miR}-203 b-3 p$ & BCL2L1 \\
\hline $\mathrm{miR}-221 / 222$ & miR-221-5p & MBD2 \\
\hline \multirow{4}{*}{$\operatorname{miR}-23 a / 27 a / 24-2$} & miR-23a-3p & ABCF1; APAF1; MARK1; PDK4; SEMA6D \\
\hline & $\operatorname{miR}-27 a-3 p$ & $\begin{array}{c}\text { BTG1; CALR; FAM172A; RXR } \alpha \text {; SFRP1; SGPP1; SMAD2; } \\
\text { TP53; VANGL }\end{array}$ \\
\hline & $\operatorname{miR}-24-5 p$ & CTNNB1 \\
\hline & $\operatorname{miR}-24-3 p$ & DHFR; DND1; VHL \\
\hline \multirow{3}{*}{$\operatorname{miR}-29 b-1 / 29 a$} & $\operatorname{miR}-29 b-3 p$ & BCL9L; GRN; SIRT1; TIAM1 \\
\hline & miR-29b-5p & SMAD3 \\
\hline & $\operatorname{miR}-29 a-3 p$ & KLF4; MMP2; PTEN; RPS15A; TNFAIP3 \\
\hline $\mathrm{miR}-301 \mathrm{~b} / 130 \mathrm{~b}$ & miR-130b-3p & ITGB1; ITGA5 \\
\hline \multirow{2}{*}{$\operatorname{miR}-452 / 224$} & $\operatorname{miR}-224-5 p$ & $\begin{array}{c}\text { CDH1; CDKN1A; CDS2; GSK3 } \beta \text {; LGALSL; MBD2; PHLPP1; } \\
\text { PHLPP2; SFRP2; SLC4A4; SMAD4; USP3 }\end{array}$ \\
\hline & miR-452-3p & GSK3 $\beta$ \\
\hline
\end{tabular}

Genes with tumour suppresor function are bolded in this table.

Next, the functional relationship between the expression of miRNAs from selected up-regulated clusters and their target genes was analysed. The most frequently targeted oncogene (four times) was catenin beta 1 (CTNNB1). The most targeted tumour suppressors were phosphatase and tensin homolog (PTEN) and gamma-amino-butyric acid type $B$ receptor 1 (GABBR1), inhibited by eight and five miRNAs, respectively. The genes SMAD7, TGFBR2 and TNFAIP3 were associated with both tumour suppressor and oncogenic roles. The target genes of miRNAs from selected clusters are listed in Table 6 and Supplementary Material S4.

For complex classification of all target genes of selected miRNAs, we used GO-Slim analysis performed by the Panther Classification System [12]. Genes were classified according to molecular function, biological processes, protein class and pathway. An overrepresentation test was used for each classification to reveal significantly enriched categories (Supplementary Material S7).

Classification according to $\mathrm{GO}$ molecular function revealed that 128 target genes could be attributed to one of the GO molecular function categories, while 54 target genes fell into the category unclassified. The most overrepresented category of GO molecular function was binding (GO:0005488), with 87 target genes, and this category was the only 
one showing significant enrichment in the overrepresentation test $(p<0.001$; FDR $<0.001)$. The results of GO-Slim molecular function analysis are provided in Figure 2.



Figure 2. GO-Slim analysis of target genes of up-regulated miRNAs in CRC. Classification is according to molecular function terms, and all terms are plotted. The significantly overrepresented term is underlined $(p<0.001 ;$ FDR $<0.001)$. FDR_false discovery rate.

Analysis according to GO-Slim biological process classified the target genes into 17 categories. The overrepresentation test showed seven significantly enriched categories $(p<0.05 ;$ FDR $<0.05)$, and 45 target genes remained in the category unclassified according to the biological process terms. The biological processes categories identified according to GO-Slim analysis are depicted in Figure 3.

\section{GO-SLIM BIOLOGICAL PROCESSES}

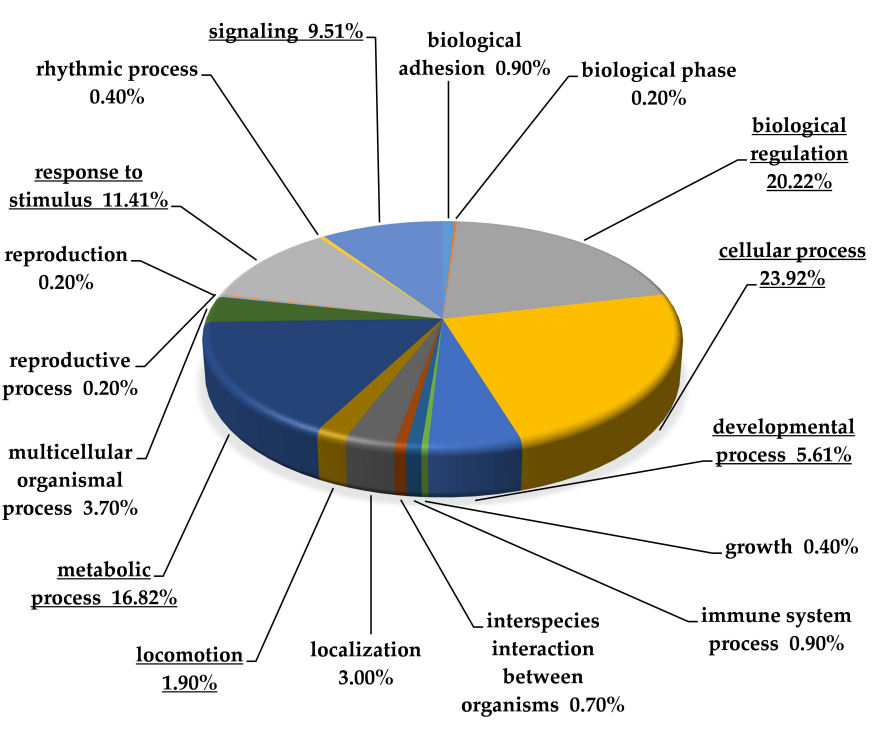

Figure 3. GO-Slim analysis of target genes of up-regulated miRNAs in CRC. Classification is according to biological processes terms. Significantly overrepresented terms are underlined $(p<0.05$; FDR < 0.05). FDR-false discovery rate. 
Analysis according to Panther protein class showed that the target genes of miRNA clusters up-regulated in CRC belonged to 19 categories, and 52 target genes fell into the category unclassified. Classification according to the protein class overrepresentation test revealed that the significantly enriched categories were protein modifying enzyme and gene-specific transcriptional regulator $(p<0.01$; FDR $<0.01)$. Figure 4 depicts all categories according to Panther protein class classification.

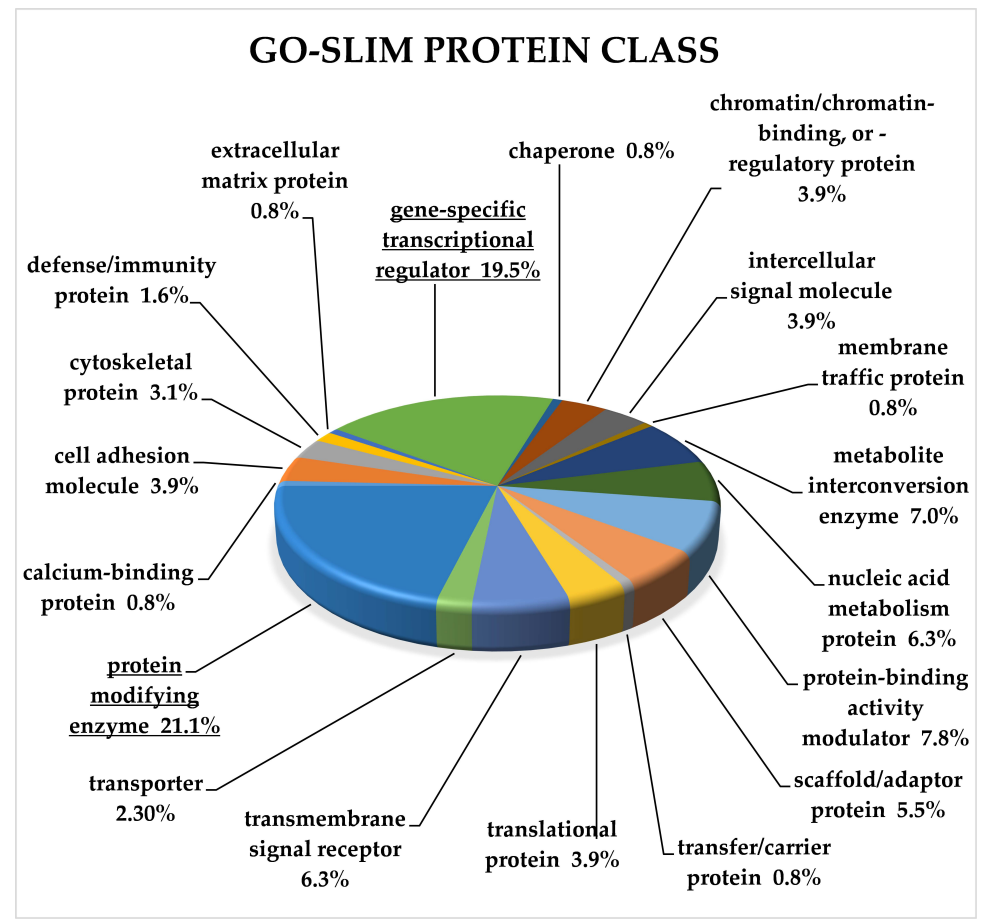

Figure 4. GO-Slim analysis of target genes of up-regulated miRNAs in CRC. Classification is according to protein class terms, and all terms are plotted. Significantly overrepresented terms are underlined $(p<0.01 ; \mathrm{FDR}<0.01)$. FDR-false discovery rate.

Analysis according to Panther pathways [12] showed that target genes were involved in 68 pathways, and 106 target genes were in the category unclassified according to Panther pathways terms. The overrepresentation test revealed 26 significantly enriched pathways. Figure 5 depicts only significantly enriched pathways according to the Panther pathways classification.

The pathway with the highest number of included genes was cholecystokinin receptor (CCKR) signalling map (P06959), which included 17 genes from our analysis. The gastrointestinal peptide hormones gastrin and cholecystokinin (CCK) are ligands of two G-protein coupled receptors: cholecystokinin 1 receptor (CCK1R) and cholecystokinin 2 receptor (CCK2R). CCK1R and CCK2R are involved in the regulation of cell proliferation and migration through several downstream signalling pathways [219]. Nine analysed genes enriched in the CCKR signalling map pathway, PTEN, FOXO1, FOXO3, KLF4, GSK3B, MYC, CCND1, TCF4 and CTNNB1, were targeted by multiple miRNAs from different families (miRNAs and their target genes are listed in Table 6 and Supplementary Material S4). 


\section{OVERREPRESENTED PANTHER PATHWAYS}

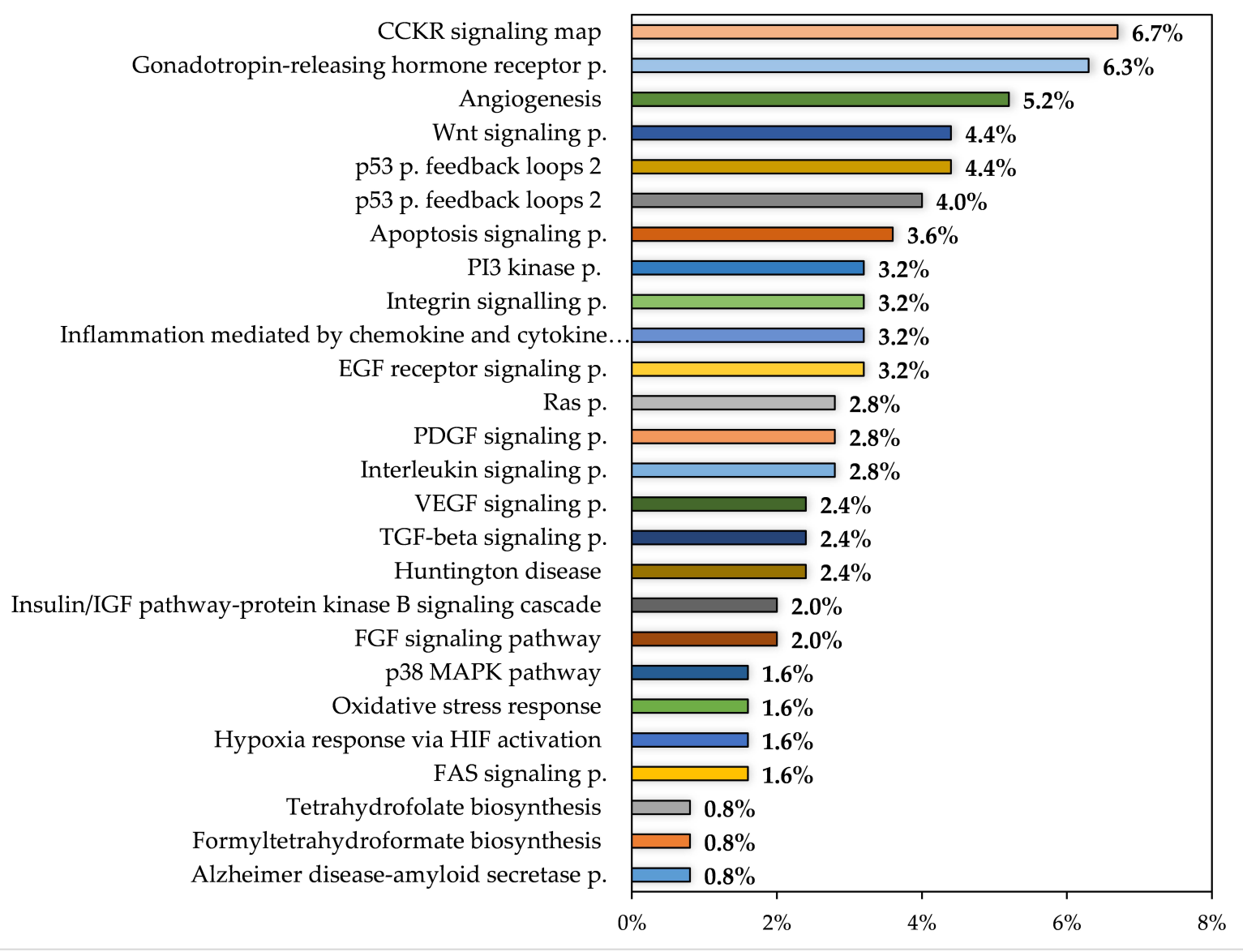

Figure 5. GO-slim analysis of target genes of up-regulated miRNAs in CRC. Classification is according to Panther pathways terms, and only significantly overrepresented terms are plotted $(p<0.05$; FDR $<0.05)$. FDR—false discovery rate.

The CCKR signalling map pathway was associated with several tumour suppressors. Among them, the gene PTEN is regulated by eight miRNAs from eight clusters, and the proapoptotic transcription factors Forkhead Box O3 (FOXO3) and Forkhead Box O1 (FOXO1), associated with the inhibition of cell proliferation and promotion of apoptosis, are targeted by miR-96-5p and miR-182-5p from the miR-182/96/183 cluster [62,220]. The zinc-finger transcription factor Krüppel-like factor 4 (KLF4), which inhibits cell proliferation and migration, is targeted by miR-92a-3p [210] and miR-29a-3p [190]. Serine-threonine kinase glycogen synthase kinase 3 beta (GSK3B) is targeted by miR-224 [221] and miR-452-3p [195] from cluster miR-452/miR-224. Down-regulation of GSK3B leads to increased cell proliferation and migration [195].

On the other hand, miR-93-5p and miR-182-5p suppress tumorigenesis in vivo and cell growth through targeting of the transcription factor MYC [222,223]. Decreased expression of CCND1 (cyclin D1) caused by the inhibitory effect of miR-93-5p, miR-18a-5p and miR-96-5p leads to decreased cell proliferation and cell cycle arrest $[167,222,224]$. The transcription factor TCF4 (transcription factor 4) and cell adhesion protein CTNNB1 promote cell proliferation and resistance to 5-FU [56]. TCF4 and CTNNB1 are targeted by miR-181a-5p [56] and miR-203a-3p [225,226]. CTNNB1 is also a target gene of miR-93-5p [222].

The gonadotropin-releasing hormone receptor pathway (P06664) was associated with 16 target genes of up-regulated miRNA clusters. GSK3B, SMAD4 and CTNNB1 were the most frequently targeted by miRNAs from several families. Signal transduction protein SMAD4, a member of the SMAD family, is a suppressor of proliferation and increases 
sensitivity to oxaliplatin [227]. SMAD4 is targeted by miR-20a-5p [155], miR-19b-3p [227] and miR-18a-5p [228] that are members of cluster miR-17/92a-1.

Thirteen genes targeted by miRNA clusters up-regulated in CRC tissue were associated with the angiogenesis (P00005) pathway. The genes KRAS, GSK3B, HIF1A and CTNNB1 were targeted by miRNAs from different families. KRAS (KRAS Proto-Oncogene, GTPase) is an oncogene frequently activated by mutation in CRC [110]. Inhibition of KRAS expression by miR-19a-3p [229] and miR-96-5p [167] leads to decreased cell growth and down-regulation of vascular endothelial growth factor A (VEGFA). Similarly, reduced expression of angiogenesis-inducing factor hypoxia induced factor- $1 \alpha$ (HIF1A) by targeting with miR-18a-5p [230] and miR-93-5p [81] leads to decreased cell growth and tumour angiogenesis inhibition in vivo.

Transcription factor p53 plays an important role in maintaining DNA integrity and regulation of the cell cycle [231]. The p53 pathway (P00059) was associated with 11 target genes; among them, the genes ATM, CDKN1A, SIRT1, THBS1 and PTEN were targeted by miRNAs from multiple families. Reduced expression of the DNA-damage repair protein ATM (ataxia telangiectasia mutated) mediated by miR-18a-5p [153] and miR-203a$3 p$ [232] leads to oxaliplatin resistance and decreased DNA repair. The kinase cyclin dependent kinase inhibitor 1A CDKN1A), also known as p21, is an important negative regulator of the cell cycle. CDKN1A is targeted by miR-224-5p [233], miR-106b [234] and miR-20a-5p [235]. Reduced expression of extracellular matrix protein thrombospondin 1 (THBS1) via interaction with miR-19a-3p [236], miR-182-5p [237] and miR-203a-3p [238] promotes proliferation and migration. Increased expression of sirtuin 1 (SIRT1) promotes cell proliferation and oxaliplatin resistance, and these effects can be reversed by targeting with miR-141-3p [78] and miR-29b-3p [239].

Oncogenic mutations of components of the Wnt signalling pathway, mostly mutations in APC (the APC regulator of WNT signalling pathway), are key factors in CRC development [231]. The Wnt signalling pathway (P00057) is associated with 11 target genes. CCND1, GSK3B, SMAD4, CTNNB1 and MYC are targeted by miRNAs with the use of different family-specific seed sequences.

Panther pathway analysis was also performed for individual miRNA clusters. Table 7 lists pathways that were significantly increased in the statistical overrepresentation test according to target genes of particular clusters. In this analysis, we only included clusters for which there were enough data about target genes (seven clusters), and clusters miR181c/181d, miR-191/425, miR-221/222, miR-23a/27a/24, miR-29b/29a, and miR-452/224 had to be omitted.

The pathways CCKR signalling map (P06959) and p53 pathway feedback loops 2 (P04398) were overrepresented in the target genes of five miRNA clusters each. The highest number of overrepresented pathways were associated with clusters miR-17/92a-1 (13 pathways) and miR-106b/93/25 (5 pathways).

Table 7. Panther pathways significantly increased in the statistical overrepresentation test according to target gene miRNAs of miRNA clusters.

\begin{tabular}{ccc}
\hline Pathway & Pathway Code & miRNA Cluster \\
\hline Angiogenesis & P00005 & $\mathrm{miR}-106 \mathrm{~b} / 93 / 25$ \\
$\mathrm{miR}-17 / 92 \mathrm{a}-1$ \\
$\mathrm{miR}-203 \mathrm{a} / 203 \mathrm{~b}$ \\
$\mathrm{miR}-106 \mathrm{~b} / 93 / 25$ \\
$\mathrm{miR}-17 / 92 \mathrm{a}-1$ \\
Apoptosis signaling pathway & P00006 & $\mathrm{miR}-181 \mathrm{a}-1 / 181 \mathrm{~b}-1 ; \mathrm{miR}-181 \mathrm{a}-2 / 181 \mathrm{~b}-2$ \\
$\mathrm{miR}-203 \mathrm{a} / 203 \mathrm{~b}$ \\
$\mathrm{miR}-17 / 92 \mathrm{a}-1$ \\
CCKR signaling map & & $\mathrm{miR}-200 \mathrm{c} / 141$ \\
Gonadotropin-releasing hormone receptor pathway & P06959 & $\mathrm{miR}-106 \mathrm{~b} / 93 / 25$ \\
miR-17/92a-1
\end{tabular}


Table 7. Cont.

\begin{tabular}{|c|c|c|}
\hline Pathway & Pathway Code & miRNA Cluster \\
\hline Integrin signalling pathway & P00034 & $\begin{array}{c}\mathrm{miR}-17 / 92 \mathrm{a}-1 \\
\mathrm{miR}-301 \mathrm{~b} / 130 \mathrm{~b}\end{array}$ \\
\hline Interferon-gamma signaling pathway & P00035 & miR-181a-1/181b-1; miR-181a-2/181b-2 \\
\hline Interleukin signaling pathway & P00036 & $\mathrm{miR}-17 / 92 \mathrm{a}-1$ \\
\hline JAK/STAT signaling pathway & P00038 & miR-181a-1/181b-1; miR-181a-2/181b-2 \\
\hline p53 pathway & P00059 & $\begin{array}{c}\mathrm{miR}-17 / 92 a-1 \\
\mathrm{miR}-203 \mathrm{a} / 203 \mathrm{~b}\end{array}$ \\
\hline p53 pathway feedback loops 2 & P04398 & $\begin{array}{c}\text { miR-106b/93/25 } \\
\text { miR-17/92a-1 } \\
\text { miR-181a-1/181b-1; miR-181a-2/181b-2 } \\
\text { miR-203a/203b }\end{array}$ \\
\hline PI3 kinase pathway & P00048 & $\begin{array}{c}\operatorname{miR}-17 / 92 a-1 \\
\operatorname{miR}-183 / 96 / 182\end{array}$ \\
\hline Ras Pathway & P04393 & miR-17/92a-1 \\
\hline TGF-beta signaling pathway & P00052 & $\begin{array}{l}\mathrm{miR}-106 \mathrm{a} / 363 \\
\mathrm{miR}-17 / 92 \mathrm{a}-1\end{array}$ \\
\hline VEGF signaling pathway & P00056 & $\operatorname{miR}-17 / 92 a-1$ \\
\hline Wnt signaling pathway & P00057 & $\operatorname{miR}-106 b / 93 / 25$ \\
\hline
\end{tabular}

\section{Discussion}

An increasing number of studies refer to the important role of miRNA dysregulation in colorectal cancer. Many usually up-regulated miRNAs have also been suggested as promising biomarkers for CRC diagnosis or prognosis assessment [2,3]. Therefore, the main aim of this systematic review was to provide selection and functional analysis of miRNA clusters up-regulated in CRC tissue.

Based on data from available experimental research studies, 15 miRNA clusters with up-regulated expression in CRC were selected. Approximately half of these clusters are embedded in intronic areas of genes, and the rest are located in intergenic regions. Many transcription factors are involved in the regulation of miRNA clusters, and among them, MYC, ZEB1 and p53 play important roles in CRC.

Increased expression of ZEB1 was associated with worse survival in several types of digestive cancers, e.g., pancreatic, gastric and colorectal cancers [240]. The transcription factor ZEB1 inhibits the expression of miRNA clusters miR-200c/141 [241], miR-183/96/182 and $\mathrm{miR}-203 \mathrm{a} / 203 \mathrm{~b}$ [242].

The transcription factor MYC seems to play an important role in CRC development through interaction with several protein coding genes and non-coding RNAs $[243,244]$. Expression of up-regulated miR-181d [34] and the clusters miR-29b-1/29a [245], miR17/92a-1 $[33,246]$ is also under the control of MYC in CRC. MYC shows miRNA specific influence as expression of miR-17/92a-1 and miR-181d is induced and expression miR-29b$1 / 29$ a is down-regulated by this transcription factor. While miR-17/92a- 1 and miR-181d are positively associated with advanced TNM stage and the presence of metastases, information about cluster miR-29b-1/29a is rather inconclusive in this respect.

The induction of miR-17/92a-1 by MYC is in good agreement with the observation that MYC expression is up-regulated in CRC tissue compared to normal tissue and it is associated with worse survival and chemoresistance. Moreover, inhibition of MYC expression led to increased apoptosis in vitro $[247,248]$. On the other, increased expression of MYC in tumour tissue was also associated with improved survival and smaller tumour size and better survival of patients with CRC [249]. As there is no straightforward explanation for these opposing observations, it seems that more research aimed at exploring the details of the biological and clinical context of measured samples is needed to reveal roles of MYC in CRC progression.

The transcription factor p53 shows a significant impact on the expression of many miRNAs from selected up-regulated clusters. In particular, p53 inhibits expression of all 
members of the cluster miR-17/92a-1, namely miR-27a, miR-29a, miR-222 and miR-224. On the other hand, p53 induces the expression of miR-106a, miR-221 and the whole miR200c/141 cluster. In general, p53 shows inhibitory rather than stimulatory effects with respect to up-regulated clusters in CRC [250,251].

It is no surprise that members of the cluster miR-17/92a-1 are convincingly associated with metastasis occurrence and poor survival in CRC patients. Members of this intronic cluster have been shown to exert a high level of co-expression amongst themselves as well as with the host gene. However, there are exceptions to this observation that can issue from the presence of binding sites of 138 transcription factors including p53, CREB1 (cAMP responsive element binding protein 1), MYC and SMAD1 (SMAD family member 1) $[250,251]$. According to Panther pathways analysis, this cluster employs 12 pathways involved in regulation of cancer progression, including p53, Ras, HIF, VEGF and TGF $\beta$ signalling pathways and some others. Within the selection of up-regulated clusters, the miR17/92a-1 cluster shows the strongest association with poor patient outcomes, it is the most studied cluster, and its effects are realised by the highest number of regulatory pathways.

On the other hand, the clusters miR-106b/93/25 and miR-183/96/182 also show strong associations with metastases occurrence in CRC patients (although the association with survival is weaker, compared with that of miR-17/92a-1). miR-106b/93/25 is, similarly to $\mathrm{miR}-17 / 92 \mathrm{a}-1$, an intronic cluster showing partial co-expression with the host gene and the potential to respond to up to 148 transcription factors, including MYC, RB1 (RB transcription corepressor 1), EGR1 (early growth response 1) and CREB1 [250,251]. Among others, miR-106b/93/25 utilises the Wnt, CCKR and p53 signalling pathways. Expression of the miR-183/96/182 cluster is regulated by 42 transcription factors, and as it is located in intergenic locus in the genome, it possesses its own TSS. Only the PI3 kinase pathway was significantly linked to miR-183/96/182, according to Panther pathway analysis.

Finally, high expression of miR-106a/363 showed a strong association with poor survival of CRC patients. Expression of miR-106a/363 seems to be regulated by 25 transcription factors [250,251], and miR-363 is likely to be regulated in a different manner to the rest of the cluster, as it frequently shows a different response to treatment and differs in correlation studies (Table 5, Supplementary Materials S2 and S3).

Clusters showing the strongest association with metastasis occurrence and/or poor survival (miR-17/92a-1, miR-106b/93/25, miR-183/96/182 and miR-106a/363) share nine regulatory domains: EP300 (E1A binding protein p300), ERG (ETS transcription factor ERG), MYC, GTF2I (General transcription factor IIi), MAX (MYC associated factor X), AR (Androgen receptor), ETS1 (ETS proto-oncogene 1), MYCN (MYCN Proto-Oncogene) and TFAP2A (Transcription factor AP-2 alpha) [250,251].

On the other hand, at least some members of the clusters miR-23a/27a/24-2, miR$203 a / 203 b$ and miR-200c/141 show tumour-suppressive functions, which is in accordance with the number of their target genes with oncogenic character. However, this regulatory relationship was not reflected in a positive correlation between high expression of miR23a/27a/24-2, miR-203a/203b and miR-200c/141 cluster members and patient survival. According to Panther pathways analysis, cluster miR-203a/203b exerts it functions via apoptosis, CCKR and the p53 signal pathway, whereas miR-200c/141 is related only to the GnRH receptor signalling pathway. The abovementioned clusters share 18 common regulatory domains: bromodomain containing 4 (BRD4), lysine demethylase 5B (KDM5B), mediator complex subunit 1 (MED1), E1A binding protein p300 (EP300), transcription factor AP-2 gamma (TFAP2C), Kruppel-like factor 5 (KLF5), ERG, MYC, MAX, E2F transcription factor 1 (E2F1), AR, aryl hydrocarbon receptor nuclear translocator like (ARNTL), HIF1A, EGR1, nuclear receptor subfamily 2 group F member 2 (NR2F2), Sp1 transcription factor (SP1), transcription factor AP-4 (TFAP4) and oestrogen receptor 1 (ESR1) [250,251].

Surprisingly, clusters with the strongest oncogenic and tumour suppressor potential share five regulatory regions (MAX, ERG, EP300, AR and MYC). The binding domains specific for oncogenic clusters are GTF2I, ETS1, MYCN and TFAP2A. Three of them, ETS1, 
MYCN and TFAP2A, have been previously associated with the cancer progression and all of them show tumour promoting effects [252-254].

The miRNA clusters listed in this study predominantly have increased expression in CRC tissue according to the analysed studies. The majority of research studies also confirmed up-regulation of all miRNAs from clusters miR-17/92a-1, miR-181a-1/181b1, miR-181a-2/181b-2, miR-181c/181d, miR-183/96/182, miR-191/425, miR-200c/141, miR-203a/203b, miR-222/221 and miR-301b/130b in the circulation of patients with CRC (Supplementary Material S2). On the other hand, in stool samples of CRC patients, only clusters miR-17/92a-1 and miR-183/96/182 exerted increased values (Table 4). This inconsistency can be attributed to many factors, including the manner in which colorectal cancer influences food intake and intestinal transition time in individual patients.

Occasionally, one or two studies were not in line with the majority of reports concerning up- or down-regulation of particular miRNA levels in tissues and/or the circulation. The reason for this may issue from the existence of several variants of mature miRNA known as isomirs [255]. Isomirs differ slightly in length due to impaired cleavage by Drosha and Dicer [256] or because of post-transcriptional modifications [255]. Rhythmic changes in the expression of several miRNAs were observed in mammalian tissues [257-259] or the circulation [260]; therefore, we assume that rhythmic expression may also increase the variability in miRNA expression measurement when sampling is not performed at the same time of day.

The expression of miRNA in tumour tissue, the circulation and stool samples was correlated with clinicopathological characteristics, survival, disease recurrence and response to chemotherapy. Up-regulated expression of clusters miR-106b/93/25, miR-17-92a-1 and $\mathrm{miR}-183 / 96 / 182$ was strongly associated with the presence of distant or lymph node metastasis (Supplementary Material S3). Worse survival of patients was convincingly associated with increased expression of clusters miR-17/92a-1 and miR-106a/363 (Table 5).

miRNAs involved in clusters with up-regulated expression in CRC tissue are frequently associated with the promotion of tumour development and show oncogenic effects. However, our study revealed exceptions to this pattern. Several up-regulated miRNAs were referred to as tumour-suppressors in studies performed under in vitro conditions with the use of CRC cell lines. The cluster miR-23a/27a/24-2 was predominantly upregulated in CRC tissue and the circulation, but miR-24-2 was also negatively correlated with advanced tumour stage and metastasis. Increased expression of miR-24 in CRC was associated mostly with a tumour-suppressor effect through the targeting of genes with oncogenic potential. This indicates that miR-24 may have a different role in CRC development from other members of the cluster, namely miR-27a and miR-23a. Similarly, members of the cluster miR-200c/141 show predominantly tumour-suppressing effects in CRC cells through targeting of oncogenes (Table 6 and Supplementary Material S4). According to these facts, we assume that the cluster miR-200c/141 could be classified as a tumour-suppressive rather than an oncogenic cluster. Target genes of the miRNA cluster miR-203a/203b in CRC cell lines were also mainly oncogenes, which implies a tumour-suppressive role of this cluster. However, the expression of miR-203a and miR-203b was predominantly increased in CRC tissue and the circulation.

GO-Slim and Panther pathway analyses of target genes were performed to better understand the regulatory role of up-regulated miRNA clusters and their target genes in CRC. Based on information from experimental studies selected according to the defined selection criteria, 181 genes were identified as experimentally proven target genes of miRNAs from clusters up-regulated in CRC tissue. The ratio of tumour suppressors and oncogenes was nearly equal, as there were 86 oncogenes and 92 tumour suppressors (and 3 genes had no clear role in oncogenesis).

GO-SLIM classification of target genes of up-regulated clusters in CRC according to class molecular function revealed that the overrepresented category was binding (GO:0005488), which is in accordance with previous studies [261,262]. 
Analysis of target genes according to GO-Slim biological process revealed seven significantly overrepresented categories: biological regulation (GO:0065007), cellular process (GO:0009987), developmental process (GO:0032502), locomotion (GO:0040011), meta-bolic process (GO:0008152), response to stimulus (GO:0050896) and signalling (GO:0023052).

Classification according to Panther protein class showed that target genes were included in 19 categories. Significantly overrepresented categories were protein modifying enzyme (PC00260) and gene-specific transcriptional regulator (PC00264).

Analysis of target genes according to Panther pathways categories revealed 26 significantly overrepresented pathways. A majority of target genes were associated with pathways CCKR signalling map (P06959), gonadotropin-releasing hormone receptor pathway (P06664), angiogenesis (P00005), Wnt signalling pathway (P00057) and p53 pathway (P00059). A previous study analysing target genes of miRNAs deregulated in CRC tissue revealed that among the 10 most enriched pathways were angiogenesis (P00005), the Wnt signalling pathway (P00057) and the p53 pathway (P00059) [263].

When Panther pathway analysis was performed separately for tumour suppressors and oncogenes, interestingly, biological process rhythmic process (GO:0048511) and pathway circadian clock system (P00015) were linked only to tumour-suppressor genes (CRY2 and FBXL3). On the other hand, the pathways cell cycle (P00013) and VEGF signalling pathway (P0056) were linked only to oncogenes (KRAS, ETS1, VEGFA, PRKCZ, HIF1A and SPHK2). Processes exclusively linked to tumour-suppressive genes were associated with cluster miR-181c/181d, whereas pathways associated only with oncogenes were used by the clusters miR-17/92a-1, miR-182/96/183, miR-106b/25/93, miR-106a/363 and miR-200c/141.

In summary, this review focused on selecting and analysing miRNA clusters with up-regulated expression in CRC. miRNAs are an intensively studied class of small noncoding RNAs with promising biomarker potential not only in tumour tissue but also in the circulation. To increase the specificity of miRNA-based diagnostics, there is a strong tendency to use panels of several miRNAs rather than a single miRNA $[217,264,265]$.

Thanks to prominent advances in in vivo delivery systems, animal and clinical studies employing miRNA administration were strongly facilitated. This effort was followed by the release of several miRNA-based therapeutics that are being clinically tested or are already being used in the treatment of a wide spectrum of diseases including cancer malformations. miR-29b-1-5p and miR-222-3p, mentioned in this review, are part of miRNA panel for diagnostic thyroid and pancreatic cancer. miR-29b is used for the treatment of fibrosis, and miR-92 turned out to be useful for treatment of ischemia [4]. However, many more miRNAs or miRNA inhibitors have been clinically tested, as reviewed elsewhere [266].

The effort of pharmaceutical companies focused on the clinical use of miRNA was reflected by thousands of patent applications in US and European patent databases. The highest number of registered patents is related to oncological diseases including colon cancer. There are several commercial companies developing miRNA-based therapeutics focused on the clinical use of miRNA. Among them, tumour-suppressor miR-34a was tested as a tool for the treatment of colon cancer. Similarly, the delivery of miR-145 and miR-33a has been tested for in vivo treatment of colon cancer [267].

miRNAs located in clusters are likely to be transcribed as a single polycistronic transcript affected by same transcription factors and epigenetic changes $[268,269]$. This feature of clustered miRNAs has not recently been involved in strategies for new drug development; however, we believe that it has strong potential to increase the efficiency of miRNA-based treatment. Considering whole clusters instead of single miRNAs can be useful, especially when whole clusters show oncostatic or tumour-promoting potential.

In this review, we also analysed interactions among miRNAs and long non-coding RNAs. lncRNAs are frequently host genes of miRNAs, and they show the capacity to inhibit miRNA effects through sponging them. Better understanding of miRNA transcriptional and post-transcriptional regulation can further facilitate development of miRNA-based therapeutics tested and/or used in cancer treatment. 


\section{Conclusions}

Our results indicate that members of clusters with up-regulated expression in CRC frequently show oncogenic potential. However, the extent of the tumour-promoting effect varies greatly among them. Overall, it is possible to conclude that clusters with up-regulated expression seem to be associated to a greater extent with worse patient prognosis, although exceptions for particular miRNAs have been reported. Similarly, when the influence of miRNAs from selected up-regulated clusters on chemotherapy is reported, it is usually in the induction of chemoresistance rather than chemosensitivity. To use up-regulated miRNAs as CRC markers would require the assumption that levels of miRNAs in cancer tissue, circulation and faeces correlate. This prerequisite is not met for all up-regulated clusters; however, it is valid for miR-17/92a-1 and miR-183/96/182. The correlation between miRNA levels in the tumour tissue and the circulation is more significant than that reported in tumour tissue and faeces. The location of up-regulated clusters is variable; however, no cluster was located in an exon. In spite of huge progress on the roles of miRNA in CRC progression, more effort to reveal the mechanisms of their action is needed, as not all members of selected up-regulated clusters could be linked to a particular intracellular pathway. Based on the abovementioned conclusions, it seems that miRNA from up-regulated clusters in CRC are promising targets for future translational research.

Supplementary Materials: The following are available online at https://www.mdpi.com/article/ 10.3390/cancers13122979/s1, Supplementary Material S1: List of included studies for selection up-regulated miRNA clusters in CRC. Supplementary Material S2: Up- or down-regulation of the analysed miRNA clusters in tumour tissue and circulation of patients with CRC. Supplementary Material S3: Association of miRNA expression with clinicopathological characteristics. Supplementary Material S4: Alphabetical list of target genes of up-regulated miRNA clusters. Supplementary Material S5: List of abbreviated lncRNA and circRNA genes. Supplementary Material S6: List of abbreviated target genes. Supplementary Material S7: Panther GO-Slim analysis-statistic data and genes classification. Supplementary Material S8 - list of references which are cited only in Supplementary Materials.

Author Contributions: P.P.—data search, data curation, statistical analysis, writing—original draft preparation, review and editing. I.H.-supervision, writing—original draft preparation, review and editing. All authors have read and agreed to the published version of the manuscript.

Funding: Research was supported by grants provided by The Slovak Research and Development Agency (grant APVV-16-0209) and by The Scientific Grant Agency of the Ministry of Education, Science, Research and Sport of the Slovak Republic and the Slovak Academy of Sciences (grant VEGA 1/0679/19).

Institutional Review Board Statement: Not applicable.

Informed Consent Statement: Not applicable.

Data Availability Statement: Data is contained within the article or Supplementary Materials.

Conflicts of Interest: The authors declare no conflict of interest.

\section{References}

1. Wong, M.C.; Huang, J.; Lok, V.; Wang, J.; Fung, F.; Ding, H.; Zheng, Z.-J. Differences in Incidence and Mortality Trends of Colorectal Cancer Worldwide Based on Sex, Age, and Anatomic Location. Clin. Gastroenterol. Hepatol. 2021, 19, 955-966.e61. [CrossRef]

2. Vishnubalaji, R.; Hamam, R.; Abdulla, M.-H.; Mohammed, M.A.V.; Kassem, M.; Al-Obeed, O.; Aldahmash, A.; Alajez, N.M. Genome-wide mRNA and miRNA expression profiling reveal multiple regulatory networks in colorectal cancer. Cell Death Dis. 2015, 6, e1614. [CrossRef]

3. Pizzini, S.; Bisognin, A.; Mandruzzato, S.; Biasiolo, M.; Facciolli, A.; Perilli, L.; Rossi, E.; Esposito, G.; Rugge, M.; Pilati, P.; et al. Impact of microRNAs on regulatory networks and pathways in human colorectal carcinogenesis and development of metastasis. BMC Genom. 2013, 14, 589. [CrossRef] 
4. Bonneau, E.; Neveu, B.; Kostantin, E.; Tsongalis, G.J.; De Guire, V. How close are miRNAs from clinical practice? A perspective on the diagnostic and therapeutic market. Electron. J. Int. Fed. Clin. Chem. Lab. Med. 2019, 30, 114-127.

5. Kim, S.; Song, M.L.; Min, H.; Hwang, I.; Baek, S.K.; Kwon, T.K.; Park, J.-W. miRNA biogenesis-associated RNase III nucleases Drosha and Dicer are upregulated in colorectal adenocarcinoma. Oncol. Lett. 2017, 14, 4379-4383. [CrossRef]

6. Stratmann, J.; Wang, C.-J.; Gnosa, S.; Wallin, Å.; Hinselwood, D.; Sun, X.-F.; Zhang, H. Dicer and miRNA in relation to clinicopathological variables in colorectal cancer patients. BMC Cancer 2011, 11, 345. [CrossRef]

7. Vychytilova-Faltejskova, P.; Kovarikova, A.S.; Grolich, T.; Prochazka, V.; Slaba, K.; Machackova, T.; Halamkova, J.; Svoboda, M.; Kala, Z.; Kiss, I.; et al. MicroRNA Biogenesis Pathway Genes Are Deregulated in Colorectal Cancer. Int. J. Mol. Sci. 2019, $20,4460$. [CrossRef] [PubMed]

8. Lai, H.-H.; Lin, L.-J.; Hung, L.-Y.; Chen, P.-S. Role of Dicer in regulating oxaliplatin resistance of colon cancer cells. Biochem. Biophys. Res. Commun. 2018, 506, 87-93. [CrossRef] [PubMed]

9. Baskerville, S. Microarray profiling of microRNAs reveals frequent coexpression with neighboring miRNAs and host genes. RNA 2005, 11, 241-247. [CrossRef] [PubMed]

10. Marsico, A.; Huska, M.R.; Lasserre, J.; Hu, H.; Vučićević, D.; Musahl, A.; Orom, U.A.; Vingron, M. PROmiRNA: A new miRNA promoter recognition method uncovers the complex regulation of intronic miRNAs. Genome Biol. 2013, 14, R84. [CrossRef]

11. Liu, B.; Shyr, Y.; Cai, J.; Liu, Q. Interplay between miRNAs and host genes and their role in cancer. Briefings Funct. Genom. 2019, 18, 255-266. [CrossRef] [PubMed]

12. Mi, H.; Ebert, D.; Muruganujan, A.; Mills, C.; Albou, L.-P.; Mushayamaha, T.; Thomas, P.D. PANTHER version 16: A revised family classification, tree-based classification tool, enhancer regions and extensive API. Nucleic Acids Res. 2021, 49, D394-D403. [CrossRef]

13. Georgakilas, G.; Vlachos, I.S.; Paraskevopoulou, M.D.; Yang, P.; Zhang, Y.; Economides, A.N.; Hatzigeorgiou, A.G. microTSS: Accurate microRNA transcription start site identification reveals a significant number of divergent pri-miRNAs. Nat. Commun. 2014, 5, 5700. [CrossRef] [PubMed]

14. Pidíkova, P.; Reis, R.; Herichova, I. miRNA Clusters with Down-Regulated Expression in Human Colorectal Cancer and Their Regulation. Int. J. Mol. Sci. 2020, 21, 4633. [CrossRef] [PubMed]

15. Mogilyansky, E.; Rigoutsos, I. The miR-17/92 cluster: A comprehensive update on its genomics, genetics, functions and increasingly important and numerous roles in health and disease. Cell Death Differ. 2013, 20, 1603-1614. [CrossRef] [PubMed]

16. Ozsolak, F.; Poling, L.L.; Wang, Z.; Liu, H.; Liu, X.S.; Roeder, R.G.; Zhang, X.; Song, J.S.; Fisher, D.E. Chromatin structure analyses identify miRNA promoters. Genes Dev. 2008, 22, 3172-3183. [CrossRef]

17. Cerami, E.; Gao, J.; Dogrusoz, U.; Gross, B.E.; Sumer, S.O.; Aksoy, B.A.; Jacobsen, A.; Byrne, C.J.; Heuer, M.L.; Larsson, E.; et al. The cBio Cancer Genomics Portal: An Open Platform for Exploring Multidimensional Cancer Genomics Data. Cancer Discov. 2012, 2, 401-404. [CrossRef]

18. Cancer Genome Atlas Network. Comprehensive molecular characterization of human colon and rectal cancer. Nature 2012, 487, 330-337. [CrossRef]

19. Gao, J.; Aksoy, B.A.; Dogrusoz, U.; Dresdner, G.; Gross, B.; Sumer, S.O.; Sun, Y.; Jacobsen, A.; Sinha, R.; Larsson, E.; et al. Integrative Analysis of Complex Cancer Genomics and Clinical Profiles Using the cBioPortal. Sci. Signal. 2013, 6, pl1. [CrossRef]

20. Thomas, M.; Lange-Grünweller, K.; Hartmann, D.; Golde, L.; Schlereth, J.; Streng, D.; Aigner, A.; Grünweller, A.; Hartmann, R.K. Analysis of Transcriptional Regulation of the Human miR-17-92 Cluster; Evidence for Involvement of Pim-1. Int. J. Mol. Sci. 2013, 14, 12273-12296. [CrossRef]

21. He, C.; Li, Z.; Chen, P.; Huang, H.; Hurst, L.D.; Chen, J. Young intragenic miRNAs are less coexpressed with host genes than old ones: Implications of miRNA-host gene coevolution. Nucleic Acids Res. 2012, 40, 4002-4012. [CrossRef]

22. Rodriguez, A.; Griffiths-Jones, S.; Ashurst, J.L.; Bradley, A. Identification of Mammalian microRNA Host Genes and Transcription Units. Genome Res. 2004, 14, 1902-1910. [CrossRef] [PubMed]

23. Pierce, M.L.; Weston, M.D.; Fritzsch, B.; Gabel, H.W.; Ruvkun, G.; Soukup, G.A. MicroRNA-183 family conservation and ciliated neurosensory organ expression. Evol. Dev. 2008, 10, 106-113. [CrossRef]

24. Dambal, S.; Shah, M.; Mihelich, B.L.; Nonn, L. The microRNA-183 cluster: The family that plays together stays together. Nucleic Acids Res. 2015, 43, 7173-7188. [CrossRef] [PubMed]

25. Saini, H.K.; Griffiths-Jones, S.; Enright, A.J. Genomic analysis of human microRNA transcripts. Proc. Natl. Acad. Sci. USA 2007, 104, 17719-17724. [CrossRef]

26. Yates, A.D.; Achuthan, P.; Akanni, W.; Allen, J.; Alvarez-Jarreta, J.; Amode, M.R.; Armean, I.M.; Azov, A.G.; Bennett, R.; Bhai, J.; et al. Ensemble. Nucleic Acids Res. 2019, 48, D682-D688. [CrossRef]

27. Sun, T.; Du, S.-Y.; Armenia, J.; Qu, F.; Fan, J.; Wang, X.; Fei, T.; Komura, K.; Liu, S.X.; Lee, G.-S.M.; et al. Expression of lncRNA MIR222HG co-transcribed from the miR-221/222 gene promoter facilitates the development of castration-resistant prostate cancer. Oncogene 2018, 7, 1-13. [CrossRef]

28. Aakko, S.; Straume, A.H.; Birkeland, E.E.; Chen, P.; Qiao, X.; 'Lønning, P.E.; Kallio, M.J. MYC-Induced miR-203b-3p and miR-203a-3p Control Bcl-xL Expression and Paclitaxel Sensitivity in Tumor Cells. Transl. Oncol. 2019, 12, 170-179. [CrossRef]

29. Javanmard, A.-R.; Dokanehiifard, S.; Bohlooli, M.; Soltani, B.M. LOC646329 long non-coding RNA sponges miR-29b-1 and regulates TGF $\beta$ signaling in colorectal cancer. J. Cancer Res. Clin. Oncol. 2020, 146, 1205-1215. [CrossRef] 
30. Biasiolo, M.; Sales, G.; Lionetti, M.; Agnelli, L.; Todoerti, K.; Bisognin, A.; Coppe, A.; Romualdi, C.; Neri, A.; Bortoluzzi, S. Impact of Host Genes and Strand Selection on miRNA and miRNA Expression. PLoS ONE 2011, 6, e23854. [CrossRef]

31. Gasiulè, S.; Dreize, N.; Kaupinis, A.; Ražanskas, R.; Čiupas, L.; Stankevičius, V.; Kapustina, Ž.; Laurinavičius, A.; Valius, M.; Vilkaitis, G. Molecular Insights into miRNA-Driven Resistance to 5-Fluorouracil and Oxaliplatin Chemotherapy: miR-23b Modulates the Epithelial-Mesenchymal Transition of Colorectal Cancer Cells. J. Clin. Med. 2019, 8, 2115. [CrossRef]

32. Wang, Y.; Luo, J.; Zhang, H.; Lu, J. microRNAs in the Same Clusters Evolve to Coordinately Regulate Functionally Related Genes. Mol. Biol. Evol. 2016, 33, 2232-2247. [CrossRef]

33. Edvardsson, K.; Nguyen-Vu, T.; Kalasekar, S.M.; Pontén, F.; Gustafsson, J.-Å.; Williams, C. Estrogen receptor expression induces changes in the microRNA pool in human colon cancer cells. Carcinogenesis 2013, 34, 1431-1441. [CrossRef] [PubMed]

34. Guo, X.; Zhu, Y.; Hong, X.; Zhang, M.; Qiu, X.; Wang, Z.; Qi, Z.; Hong, X. miR-181d and c-myc-mediated inhibition of CRY2 and FBXL3 reprograms metabolism in colorectal cancer. Cell Death Dis. 2017, 8, e2958. [CrossRef] [PubMed]

35. Draht, M.X.G.; Goudkade, D.; Koch, A.; Grabsch, H.I.; Weijenberg, M.P.; Van Engeland, M.; Melotte, V.; Smits, K.M. Prognostic DNA methylation markers for sporadic colorectal cancer: A systematic review. Clin. Epigenetics 2018, 10, 1-16. [CrossRef] [PubMed]

36. Hur, K.; Toiyama, Y.; Takahashi, M.; Balaguer, F.; Nagasaka, T.; Koike, J.; Hemmi, H.; Koi, M.; Boland, C.R.; Goel, A. MicroRNA200c modulates epithelial-to-mesenchymal transition (EMT) in human colorectal cancer metastasis. Gut 2012, 62, 1315-1326. [CrossRef] [PubMed]

37. Taheri, Z.; Aghdaei, H.A.; Irani, S.; Modarressi, M.H.; Noormohammadi, Z. Clinical correlation of miR-200c/141 cluster DNA methylation and miR-141 expression with the clinicopathological features of colorectal primary lesions/tumors. Rep. Biochem. Mol. Biol. 2019, 8, 208-215.

38. Kawasaki, Y.; Matsumura, K.; Miyamoto, M.; Tsuji, S.; Okuno, M.; Suda, S.; Hiyoshi, M.; Kitayama, J.; Akiyama, T. REG4 is a transcriptional target of GATA6 and is essential for colorectal tumorigenesis. Sci. Rep. 2015, 5, 14291. [CrossRef]

39. Fernandes, J.C.R.; Acuña, S.M.; Aoki, J.I.; Floeter-Winter, L.M.; Muxel, S.M. Long Non-Coding RNAs in the Regulation of Gene Expression: Physiology and Disease. Non-Coding RNA 2019, 5, 17. [CrossRef]

40. Hu, G.; Niu, F.; Humburg, B.A.; Liao, K.; Bendi, V.S.; Callen, S.; Fox, H.S.; Buch, S. Molecular mechanisms of long noncoding RNAs and their role in disease pathogenesis. Oncotarget 2018, 9, 18648-18663. [CrossRef]

41. Chen, S.; Liu, Y.; Wang, Y.; Xue, Z. LncRNA CCAT1 Promotes Colorectal Cancer Tumorigenesis Via A miR-181b-5p/TUSC3 Axis. OncoTargets Ther. 2019, 12, 9215-9225. [CrossRef]

42. Shang, A.; Wang, W.; Gu, C.; Chen, W.; Lu, W.; Sun, Z.; Li, D. Long non-coding RNA CCAT1 promotes colorectal cancer progression by regulating miR-181a-5p expression. Aging 2020, 12, 8301-8320. [CrossRef] [PubMed]

43. Gao, Z.; Zhou, H.; Wang, Y.; Chen, J.; Ou, Y. Regulatory effects of lncRNA ATB targeting miR-200c on proliferation and apoptosis of colorectal cancer cells. J. Cell. Biochem. 2020, 121, 332-343. [CrossRef] [PubMed]

44. Liu, X.; Wang, C. Long non-coding RNA ATB is associated with metastases and promotes cell invasion in colorectal cancer via sponging miR-141-3p. Exp. Ther. Med. 2020, 20, 1. [CrossRef] [PubMed]

45. Villegas, V.E.; Zaphiropoulos, P.G. Neighboring Gene Regulation by Antisense Long Non-Coding RNAs. Int. J. Mol. Sci. 2015, 16, 3251-3266. [CrossRef] [PubMed]

46. Sun, Z.; Shao, B.; Liu, Z.; Dang, Q.; Guo, Y.; Chen, C.; Guo, Y.; Chen, Z.; Liu, J.; Hu, S.; et al. LINC01296/miR-141-3p/ZEB1-ZEB2 axis promotes tumor metastasis via enhancing epithelial-mesenchymal transition process. J. Cancer 2021, 12, 2723-2734. [CrossRef]

47. Wu, G.; Xue, M.; Zhao, Y.; Han, Y.; Li, C.; Zhang, S.; Zhang, J.; Xu, J. Long noncoding RNA ZEB1-AS1 acts as a Sponge of miR-141-3p to Inhibit Cell Proliferation in Colorectal Cancer. Int. J. Med. Sci. 2020, 17, 1589-1597. [CrossRef]

48. Lin, M.; Li, Y.; Xian, J.; Chen, J.; Feng, Y.; Mao, C.; Pan, Y.; Li, Z.; Zeng, Y.; Yang, L.; et al. Long non-coding RNA AGER-1 inhibits colorectal cancer progression through sponging miR-182. Int. J. Biol. Markers 2020, 35, 10-18. [CrossRef]

49. Ma, S.; Yang, D.; Liu, Y.; Wang, Y.; Lin, T.; Li, Y.; Yang, S.; Zhang, W.; Zhang, R. LncRNA BANCR promotes tumorigenesis and enhances adriamycin resistance in colorectal cancer. Aging 2018, 10, 2062-2078. [CrossRef]

50. Wei, H.; Yang, Z.; Lin, B. Overexpression of long non coding RNA CA3-AS1 suppresses proliferation, invasion and promotes apoptosis via miRNA-93/PTEN axis in colorectal cancer. Gene 2019, 687, 9-15. [CrossRef] [PubMed]

51. Xu, X.-W.; Zheng, B.-A.; Hu, Z.-M.; Qian, Z.-Y.; Huang, C.-J.; Liu, X.-Q.; Wu, W.-D. Circular RNA hsa_circ_000984 promotes colon cancer growth and metastasis by sponging miR-106b. Oncotarget 2017, 8, 91674-91683. [CrossRef]

52. Shen, T.; Cheng, X.; Liu, X.; Xia, C.; Zhang, H.; Pan, D.; Zhang, X.; Li, Y. Circ_0026344 restrains metastasis of human colorectal cancer cells via miR-183. Artif. Cells Nanomed. Biotechnol. 2019, 47, 4038-4045. [CrossRef]

53. Zhang, J.; Liu, H.; Zhao, P.; Zhou, H.; Mao, T. Has_circ_0055625 from circRNA profile increases colon cancer cell growth by sponging miR-106b-5p. J. Cell. Biochem. 2019, 120, 3027-3037. [CrossRef]

54. Lu, X.; Yu, Y.; Liao, F.; Tan, S. Homo Sapiens Circular RNA 0079993 (hsa_circ_0079993) of the POLR2J4 Gene Acts as an Oncogene in Colorectal Cancer Through the microRNA-203a-3p.1 and CREB1 Axis. Med. Sci. Monit. 2019, 25, 6872-6883. [CrossRef]

55. Miao, X.; Xi, Z.; Zhang, Y.; Li, Z.; Huang, L.; Xin, T.; Shen, R.; Wang, T. Circ-SMARCA5 suppresses colorectal cancer progression via downregulating miR-39-3p and upregulating ARID4B. Dig. Liver Dis. 2020, 52, 1494-1502. [CrossRef] [PubMed]

56. Han, P.; Li, J.-W.; Zhang, B.-M.; Lv, J.-C.; Li, Y.-M.; Gu, X.-Y.; Yu, Z.-W.; Jia, Y.-H.; Bai, X.-F.; Li, L.; et al. The lncRNA CRNDE promotes colorectal cancer cell proliferation and chemoresistance via miR-181a-5p-mediated regulation of Wnt/ $\beta$-catenin signaling. Mol. Cancer 2017, 16, 1-13. [CrossRef] 
57. Zhou, T.; Wu, L.; Ma, N.; Tang, F.; Yu, Z.; Jiang, Z.; Li, Y.; Zong, Z.; Hu, K. SOX9-activated FARSA-AS1 predetermines cell growth, stemness, and metastasis in colorectal cancer through upregulating FARSA and SOX. Cell Death Dis. 2020, 11, 1071. [CrossRef] [PubMed]

58. Shen, B.; Yuan, Y.; Zhang, Y.; Yu, S.; Peng, W.; Huang, X.; Feng, J. Long non-coding RNA FBXL19-AS1 plays oncogenic role in colorectal cancer by sponging miR-203. Biochem. Biophys. Res. Commun. 2017, 488, 67-73. [CrossRef]

59. Xu, Y.; Qiu, A.; Peng, F.; Tan, X.; Wang, J.; Gong, X. Exosomal transfer of circular RNA FBXW7 ameliorates the chemoresistance to oxaliplatin in colorectal cancer by sponging miR-18b-5p. Neoplasma 2021, 68, 108-118. [CrossRef] [PubMed]

60. Yin, S.L.; Xiao, F.; Liu, Y.F.; Chen, H.; Guo, G.C. Long non-coding RNA FENDRR restrains the aggressiveness of CRC via regulating miR-18a-5p/ING4 axis. J. Cell. Biochem. 2019, 121, 3973-3985. [CrossRef] [PubMed]

61. Zhang, M.; Jiang, X.; Jiang, S.; Guo, Z.; Zhou, Q.; He, J. LncRNA FOXD2-AS1 Regulates miR-25-3p/Sema4c Axis To Promote The Invasion And Migration Of Colorectal Cancer Cells. Cancer Manag. Res. 2019, 11, 10633-10639. [CrossRef] [PubMed]

62. Cheng, K.; Zhao, Z.; Wang, G.; Wang, J.; Zhu, W. lncRNA GAS5 inhibits colorectal cancer cell proliferation via the miR-1825p/FOXO3a axis. Oncol. Rep. 2018, 40, 2371-2380. [CrossRef] [PubMed]

63. Ren, J.; Ding, L.; Zhang, D.; Shi, G.; Xu, Q.; Shen, S.; Wang, Y.; Wang, T.; Hou, Y. Carcinoma-associated fibroblasts promote the stemness and chemoresistance of colorectal cancer by transferring exosomal lncRNA H. Theranostics 2018, 8, 3932-3948. [CrossRef]

64. Ding, D.; Li, C.; Zhao, T.; Li, D.; Yang, L.; Zhang, B. LncRNA H19/miR-29b-3p/PGRN Axis Promoted Epithelial-Mesenchymal Transition of Colorectal Cancer Cells by Acting on Wnt Signaling. Mol. Cells 2018, 41, 423-435.

65. Jiang, Z.; Li, L.; Hou, Z.; Liu, W.; Wang, H.; Zhou, T.; Li, Y.; Chen, S. LncRNA HAND2-AS1 inhibits 5-fluorouracil resistance by modulating miR-20a/PDCD4 axis in colorectal cancer. Cell. Signal. 2020, 66, 109483. [CrossRef]

66. Liu, Y.; Chen, X.; Chen, X.; Liu, J.; Gu, H.; Fan, R.; Ge, H. Long non-coding RNA HOTAIR knockdown enhances radiosensitivity through regulating microRNA-93/ATG12 axis in colorectal cancer. Cell Death Dis. 2020, 11, 1-14. [CrossRef]

67. Xiao, Z.; Qu, Z.; Chen, Z.; Fang, Z.; Zhou, K.; Huang, Z.; Guo, X.; Zhang, Y. LncRNA HOTAIR is a Prognostic Biomarker for the Proliferation and Chemoresistance of Colorectal Cancer via MiR-203a-3p-Mediated Wnt/ß-Catenin Signaling Pathway. Cell. Physiol. Biochem. 2018, 46, 1275-1285. [CrossRef] [PubMed]

68. Ren, T.; Hou, J.; Liu, C.; Shan, F.; Xiong, X.; Qin, A.; Chen, J.; Ren, W. The long non-coding RNA HOTAIRM1 suppresses cell progression via sponging endogenous miR-17-5p/ B-cell translocation gene 3 (BTG3) axis in 5-fluorouracil resistant colorectal cancer cells. Biomed. Pharmacother. 2019, 117, 109171. [CrossRef]

69. Liu, K.; Yao, H.; Wen, Y.; Zhao, H.; Zhou, N.; Lei, S.; Xiong, L. Functional role of a long non-coding RNA LIFR-AS1/miR29a/TNFAIP3 axis in colorectal cancer resistance to pohotodynamic therapy. Biochim. Biophys. Acta Mol. Basis Dis. 2018, 1864, 2871-2880. [CrossRef]

70. Zhan, J.; Tong, J.; Fu, Q. Long non-coding RNA LINC00858 promotes TP53-wild-type colorectal cancer progression by regulating the microRNA-25-3p/SMAD7 axis. Oncol. Rep. 2020, 43, 1267-1277. [CrossRef]

71. Yu, X.; Mi, L.; Dong, J.; Zou, J. Long intergenic non-protein-coding RNA 1567 (LINC01567) acts as a "sponge" against microRNA93 in regulating the proliferation and tumorigenesis of human colon cancer stem cells. BMC Cancer 2017, 17, 716. [CrossRef]

72. Yang, Z.; An, Y.; Wang, N.; Dong, X.; Kang, H. LINC02595 promotes tumor progression in colorectal cancer by inhibiting miR-203b-3p activity and facilitating BCL2L1 expression. J. Cell. Physiol. 2020, 235, 7449-7464. [CrossRef]

73. Xie, J.J.; Li, W.H.; Li, X.; Ye, W.; Shao, C.F. LncRNA MALAT1 promotes colorectal cancer development by sponging miR-363-3p to regulate EZH2 expression. J. Boil. Regul. Homeost. Agents 2019, 33, 331-343.

74. Zhuang, M.; Zhao, S.; Jiang, Z.; Wang, S.; Sun, P.; Quan, J.; Yan, D.; Wang, X. MALAT1 sponges miR-106b-5p to promote the invasion and metastasis of colorectal cancer via SLAIN2 enhanced microtubules mobility. EBioMedicine 2019, 41, 286-298. [CrossRef] [PubMed]

75. Tang, D.; Yang, Z.; Long, F.; Luo, L.; Yang, B.; Zhu, R.; Sang, X.; Cao, G. Inhibition of MALAT1 reduces tumor growth and metastasis and promotes drug sensitivity in colorectal cancer. Cell. Signal. 2019, 57, 21-28. [CrossRef] [PubMed]

76. Wang, H.; Li, H.; Zhang, L.; Yang, D. Overexpression of MEG3 sensitizes colorectal cancer cells to oxaliplatin through regulation of miR-141/PDCD4 axis. Biomed. Pharmacother. 2018, 106, 1607-1615. [CrossRef] [PubMed]

77. Zhao, L.; Liu, C.; Yan, S.; Hu, G.; Xiang, K.; Xiang, H.; Yu, H. LINC00657 promotes colorectal cancer stem-like cell invasion by functioning as a miR-203a sponge. Biochem. Biophys. Res. Commun. 2020, 529, 500-506. [CrossRef] [PubMed]

78. Sun, X.; Bai, Y.; Yang, C.; Hu, S.; Hou, Z.; Wang, G. RETRACTED ARTICLE: Long noncoding RNA SNHG15 enhances the development of colorectal carcinoma via functioning as a ceRNA through miR-141/SIRT1/Wnt/ $\beta$-catenin axis. Artif. Cells Nanomed. Biotechnol. 2019, 47, 2536-2544. [CrossRef] [PubMed]

79. Horita, K.; Kurosaki, H.; Nakatake, M.; Ito, M.; Kono, H.; Nakamura, T. Long noncoding RNA UCA1 enhances sensitivity to oncolytic vaccinia virus by sponging miR-18a/miR-182 and modulating the Cdc42/filopodia axis in colorectal cancer. Biochem. Biophys. Res. Commun. 2019, 516, 831-838. [CrossRef]

80. Zhou, F.; Shen, F.; Zheng, Z.; Ruan, J. The LncRNA XIRP2-AS1 predicts favorable prognosis in colon cancer. OncoTargets Ther. 2019, 12, 5767-5778. [CrossRef]

81. Yang, L.; Cao, M.; Zhang, J.; Li, X.; Sun, Q. LncRNA XIST modulates HIF-1A/AXL signaling pathway by inhibiting miR-93-5p in colorectal cancer. Mol. Genet. Genom. Med. 2020, 8, e1112. [CrossRef] 
82. Lv, S.-Y.; Shan, T.-D.; Pan, X.-T.; Tian, Z.-B.; Liu, X.-S.; Liu, F.-G.; Sun, X.-G.; Xue, H.-G.; Li, X.-H.; Han, Y.; et al. The lncRNA ZEB1-AS1 sponges miR-181a-5p to promote colorectal cancer cell proliferation by regulating Wnt/ $\beta$-catenin signaling. Cell Cycle 2018, 17, 1245-1254. [CrossRef] [PubMed]

83. Glažar, P.; Papavasileiou, P.; Rajewsky, N. circBase: A database for circular RNAs. RNA 2014, 20, 1666-1670. [CrossRef]

84. Shin, C.; Nam, J.-W.; Farh, K.K.-H.; Chiang, H.R.; Shkumatava, A.; Bartel, D.P. Expanding the MicroRNA Targeting Code: Functional Sites with Centered Pairing. Mol. Cell 2010, 38, 789-802. [CrossRef] [PubMed]

85. Jeong, G.; Lim, Y.-H.; Kim, N.J.; Wee, G.; Kim, Y.K. Knockout of miR-221 and miR-222 reveals common and specific targets for paralogous miRNAs. RNA Biol. 2017, 14, 197-205. [CrossRef] [PubMed]

86. Guo, L.; Zhao, Y.; Zhang, H.; Yang, S.; Chen, F. Integrated evolutionary analysis of human miRNA gene clusters and families implicates evolutionary relationships. Gene 2014, 534, 24-32. [CrossRef] [PubMed]

87. Agarwal, V.; Bell, G.W.; Nam, J.-W.; Bartel, D.P. Predicting effective microRNA target sites in mammalian mRNAs. eLife 2015, 4, e05005. [CrossRef]

88. Osumi, H.; Shinozaki, E.; Yamaguchi, K.; Zembutsu, H. Clinical utility of circulating tumor DNA for colorectal cancer. Cancer Sci. 2019, 110, 1148-1155. [CrossRef]

89. Jurj, A.; Zanoaga, O.; Braicu, C.; Lazar, V.; Tomuleasa, C.; Irimie, A.; Berindan-Neagoe, I. A Comprehensive Picture of Extracellular Vesicles and Their Contents. Molecular Transfer to Cancer Cells. Cancers 2020, 12, 298. [CrossRef]

90. Dai, J.; Su, Y.; Zhong, S.; Cong, L.; Liu, B.; Yang, J.; Tao, Y.; He, Z.; Chen, C.; Jiang, Y. Exosomes: Key players in cancer and potential therapeutic strategy. Signal. Transduct. Target. Ther. 2020, 5, 145. [CrossRef]

91. Arroyo, J.D.; Chevillet, J.; Kroh, E.M.; Ruf, I.K.; Pritchard, C.C.; Gibson, D.F.; Mitchell, P.; Bennett, C.F.; Pogosova-Agadjanyan, E.L.; Stirewalt, D.L.; et al. Argonaute2 complexes carry a population of circulating microRNAs independent of vesicles in human plasma. Proc. Natl. Acad. Sci. USA 2011, 108, 5003-5008. [CrossRef]

92. Pritchard, C.C.; Kroh, E.; Wood, B.; Arroyo, J.D.; Dougherty, K.J.; Miyaji, M.M.; Tait, J.F.; Tewari, M. Blood Cell Origin of Circulating MicroRNAs: A Cautionary Note for Cancer Biomarker Studies. Cancer Prev. Res. 2012, 5, 492-497. [CrossRef] [PubMed]

93. Tai, Y.; Chen, K.; Hsieh, J.; Shen, T. Exosomes in cancer development and clinical applications. Cancer Sci. 2018, 109, 2364-2374. [CrossRef] [PubMed]

94. Jaiswal, R.; Sedger, L.M. Intercellular Vesicular Transfer by Exosomes, Microparticles and Oncosomes-Implications for Cancer Biology and Treatments. Front. Oncol. 2019, 9, 125. [CrossRef] [PubMed]

95. Baj-Krzyworzeka, M.; Mytar, B.; Szatanek, R.; Surmiak, M.; Węglarczyk, K.; Baran, J.; Siedlar, M. Colorectal cancer-derived microvesicles modulate differentiation of human monocytes to macrophages. J. Transl. Med. 2016, 14, 1-15. [CrossRef]

96. Yue, B.; Sun, B.; Liu, C.; Zhao, S.; Zhang, D.; Yu, F.; Yan, D. Long non-coding RNA Fer-1-like protein 4 suppresses oncogenesis and exhibits prognostic value by associating with miR-106a-5p in colon cancer. Cancer Sci. 2015, 106, 1323-1332. [CrossRef]

97. Ng, E.K.-O.; Chong, W.W.S.; Jin, H.; Lam, E.K.Y.; Shin, V.Y.; Yu, J.; Poon, T.C.W.; Ng, S.S.M.; Sung, J.J.Y. Differential expression of microRNAs in plasma of patients with colorectal cancer: A potential marker for colorectal cancer screening. Gut 2009, 58, 1375-1381. [CrossRef]

98. Pesta, M.; Kucera, R.; Topolcan, O.; Karlikova, M.; Houfkova, K.; Polivka, J.; Macanova, T.; Machova, I.; Slouka, D.; Kulda, V. Plasma microRNA Levels Combined with CEA and CA19-9 in the Follow-Up of Colorectal Cancer Patients. Cancers 2019, 11, 864. [CrossRef] [PubMed]

99. Huang, Z.; Huang, D.; Ni, S.; Peng, Z.; Sheng, W.; Du, X. Plasma microRNAs are promising novel biomarkers for early detection of colorectal cancer. Int. J. Cancer 2009, 127, 118-126. [CrossRef]

100. Perilli, L.; Vicentini, C.; Agostini, M.; Pizzini, S.; Pizzi, M.; D’Angelo, E.; Bortoluzzi, S.; Mandruzzato, S.; Mammano, E.; Rugge, M.; et al. Circulating miR-182 is a biomarker of colorectal adenocarcinoma progression. Oncotarget 2014, 5, 6611-6619. [CrossRef] [PubMed]

101. Li, L.; Guo, Y.; Chen, Y.; Wang, J.; Zhen, L.; Guo, X.; Liu, J.; Jing, C. The Diagnostic Efficacy and Biological Effects of microRNA-29b for Colon Cancer. Technol. Cancer Res. Treat. 2016, 15, 772-779. [CrossRef]

102. Ogata-Kawata, H.; Izumiya, M.; Kurioka, D.; Honma, Y.; Yamada, Y.; Furuta, K.; Gunji, T.; Ohta, H.; Okamoto, H.; Sonoda, H.; et al. Circulating Exosomal microRNAs as Biomarkers of Colon Cancer. PLoS ONE 2014, 9, e92921. [CrossRef] [PubMed]

103. Ostenfeld, M.S.; Jensen, S.G.; Jeppesen, D.; Christensen, L.-L.; Thorsen, S.B.; Stenvang, J.; Hvam, M.L.; Thomsen, A.; Mouritzen, P.; Rasmussen, M.; et al. miRNA profiling of circulating EpCAM+extracellular vesicles: Promising biomarkers of colorectal cancer. J. Extracell. Vesicles 2016, 5, 31488. [CrossRef] [PubMed]

104. Li, J.; Liu, Y.; Wang, C.; Deng, T.; Liang, H.; Wang, Y.; Huang, D.; Fan, Q.; Wang, X.; Ning, T.; et al. Serum miRNA expression profile as a prognostic biomarker of stage II/III colorectal adenocarcinoma. Sci. Rep. 2015, 5, 12921. [CrossRef]

105. Li, X.; Zhang, X.; Zhang, Q.; Lin, R. miR-182 contributes to cell proliferation, invasion and tumor growth in colorectal cancer by targeting DAB2IP. Int. J. Biochem. Cell Biol. 2019, 111, 27-36. [CrossRef] [PubMed]

106. Nikolouzakis, T.K.; Vassilopoulou, L.; Fragkiadaki, P.; Sapsakos, T.M.; Papadakis, G.Z.; Spandidos, D.; Tsatsakis, A.; Tsiaoussis, J. Improving diagnosis, prognosis and prediction by using biomarkers in CRC patients (Review). Oncol. Rep. 2018, 39, $2455-2472$. [CrossRef] 
107. Ahmed, F.E.; Ahmed, N.C.; Vos, P.W.; Bonnerup, C.; Atkins, J.N.; Casey, M.; Nuovo, G.J.; Naziri, W.; Wiley, J.E.; Mota, H.; et al. Diagnostic microRNA markers to screen for sporadic human colon cancer in stool: I. Proof of principle. Cancer Genom. Proteom. 2013, 10, 93-113.

108. Aghabozorgi, A.S.; Sarabi, M.M.; Jafarzadeh-Esfehani, R.; Koochakkhani, S.; Hassanzadeh, M.; Kavousipour, S.; Eftekhar, E. Molecular determinants of response to 5-fluorouracil-based chemotherapy in colorectal cancer: The undisputable role of microribonucleic acids. World J. Gastrointest. Oncol. 2020, 12, 942-956. [CrossRef]

109. Loktionov, A. Biomarkers for detecting colorectal cancer non-invasively: DNA, RNA or proteins? World J. Gastrointest. Oncol. 2020, 12, 124-148. [CrossRef]

110. Gonzalez-Pons, M.; Cruz-Correa, M. Colorectal Cancer Biomarkers: Where Are We Now? BioMed Res. Int. 2015, $2015,1-14$. [CrossRef]

111. Yau, T.O.; Tang, C.-M.; Harriss, E.K.; Dickins, B.; Polytarchou, C. Faecal microRNAs as a non-invasive tool in the diagnosis of colonic adenomas and colorectal cancer: A meta-analysis. Sci. Rep. 2019, 9, 1-13. [CrossRef]

112. Ahlquist, D.A.; Harrington, J.J.; Burgart, L.J.; Roche, P.C. Morphometric analysis of the "mucocellular layer" overlying colorectal cancer and normal mucosa: Relevance to exfoliation and stool screening. Hum. Pathol. 2000, 31, 51-57. [CrossRef]

113. Yamazaki, N.; Koga, Y.; Yamamoto, S.; Kakugawa, Y.; Otake, Y.; Hayashi, R.; Saito, N.; Matsumura, Y. Application of the Fecal MicroRNA Test to the Residuum from the Fecal Occult Blood Test. Jpn. J. Clin. Oncol. 2013, 43, 726-733. [CrossRef] [PubMed]

114. Rotelli, M.T.; Di Lena, M.; Cavallini, A.; Lippolis, C.; Bonfrate, L.; Chetta, N.; Portincasa, P.; Altomare, D.F. Fecal microRNA profile in patients with colorectal carcinoma before and after curative surgery. Int. J. Color. Dis. 2015, 30, 891-898. [CrossRef]

115. Koga, Y.; Yasunaga, M.; Takahashi, A.; Kuroda, J.; Moriya, Y.; Akasu, T.; Fujita, S.; Yamamoto, S.; Baba, H.; Matsumura, Y. MicroRNA Expression Profiling of Exfoliated Colonocytes Isolated from Feces for Colorectal Cancer Screening. Cancer Prev. Res. 2010, 3, 1435-1442. [CrossRef] [PubMed]

116. Choi, H.H.; Cho, Y.-S.; Choi, J.H.; Kim, H.-K.; Kim, S.S.; Chae, H.-S. Stool-Based miR-92a and miR-144* as Noninvasive Biomarkers for Colorectal Cancer Screening. Oncology 2019, 97, 173-179. [CrossRef]

117. Yau, T.O.; Wu, C.W.; Dong, Y.; Tang, C.-M.; Ng, S.S.M.; Chan, F.K.; Sung, J.J.Y.; Yu, J. microRNA-221 and microRNA-18a identification in stool as potential biomarkers for the non-invasive diagnosis of colorectal carcinoma. Br. J. Cancer 2014, 111, 1765-1771. [CrossRef]

118. Zhu, Y.; Xu, A.; Li, J.; Fu, J.; Wang, G.; Yang, Y.; Cui, L.; Sun, J. Fecal miR-29a and miR-224 as the noninvasive biomarkers for colorectal cancer. Cancer Biomark. 2016, 16, 259-264. [CrossRef]

119. Duran-Sanchon, S.; Moreno, L.; Augé, J.M.; Serra-Burriel, M.; Cuatrecasas, M.; Moreira, L.; Martín, A.; Serradesanferm, A.; Pozo, À.; Costa, R.; et al. Identification and Validation of MicroRNA Profiles in Fecal Samples for Detection of Colorectal Cancer. Gastroenterology 2020, 158, 947-957.e4. [CrossRef]

120. Rapado-González, Ó.; Majem, B.; Álvarez-Castro, A.; Díaz-Peña, R.; Abalo, A.; Suárez-Cabrera, L.; Gil-Moreno, A.; Santamaría, A.; López-López, R.; Muinelo-Romay, L.; et al. A Novel Saliva-Based miRNA Signature for Colorectal Cancer Diagnosis. J. Clin. Med. 2019, 8, 2029. [CrossRef]

121. Pita-Fernández, S.; González-Sáez, L.; López-Calviño, B.; Seoane-Pillado, T.; Rodríguez-Camacho, E.; Pazos-Sierra, A.; González-Santamaría, P.; Pértega-Díaz, S. Effect of diagnostic delay on survival in patients with colorectal cancer: A retrospective cohort study. BMC Cancer 2016, 16, 1-11. [CrossRef]

122. Song, M.; Emilsson, L.; Bozorg, S.R.; Nguyen, L.H.; Joshi, A.D.; Staller, K.; Nayor, J.; Chan, A.T.; Ludvigsson, J.F. Risk of colorectal cancer incidence and mortality after polypectomy: A Swedish record-linkage study. Lancet Gastroenterol. Hepatol. 2020, 5, 537-547. [CrossRef]

123. Hamzehzadeh, L.; Yousefi, M.; Ghaffari, S.-H. Colorectal Cancer Screening: A Comprehensive Review to Recent Non-Invasive Methods. Int. J. Hematol. Stem Cell Res. 2017, 11, 250-261.

124. Vychytilova-Faltejskova, P.; Radova, L.; Sachlova, M.; Kosarova, Z.; Slaba, K.; Fabian, P.; Grolich, T.; Prochazka, V.; Kala, Z.; Svoboda, M.; et al. Serum-based microRNA signatures in early diagnosis and prognosis prediction of colon cancer. Carcinogenesis 2016, 37, 941-950. [CrossRef] [PubMed]

125. Luo, H.; Shen, K.; Li, B.; Li, R.; Wang, Z.; Xie, Z. Clinical significance and diagnostic value of serum NSE, CEA, CA19-9, CA125 and CA242 levels in colorectal cancer. Oncol. Lett. 2020, 20, 742-750. [CrossRef]

126. Jelski, W.; Mroczko, B. Biochemical Markers of Colorectal Cancer-Present and Future. Cancer Manag. Res. 2020, 12 , $4789-4797$. [CrossRef]

127. Mitchell, P.S.; Parkin, R.K.; Kroh, E.M.; Fritz, B.R.; Wyman, S.K.; Pogosova-Agadjanyan, E.L.; Peterson, A.; Noteboom, J.; O'Briant, K.C.; Allen, A.; et al. Circulating microRNAs as stable blood-based markers for cancer detection. Proc. Natl. Acad. Sci. USA 2008, 105, 10513-10518. [CrossRef]

128. Köberle, V.; Pleli, T.; Schmithals, C.; Alonso, E.A.; Haupenthal, J.; Bonig, H.; Peveling-Oberhag, J.; Biondi, R.M.; Zeuzem, S.; Kronenberger, B.; et al. Differential Stability of Cell-Free Circulating microRNAs: Implications for Their Utilization as Biomarkers. PLoS ONE 2013, 8, e75184. [CrossRef]

129. Liu, H.; Liu, T.; Wu, H.; Chen, Y.; Tseng, Y.; Yao, C.; Weng, S.; Dong, L.; Shen, X. Serum micro RNA signatures and metabolomics have high diagnostic value in colorectal cancer using two novel methods. Cancer Sci. 2018, 109, 1185-1194. [CrossRef] 
130. Bovell, L.C.; Shanmugam, C.; Putcha, B.D.K.; Katkoori, V.R.; Zhang, B.; Bae, S.; Singh, K.P.; Grizzle, W.E.; Manne, U. The Prognostic Value of MicroRNAs Varies with Patient Race/Ethnicity and Stage of Colorectal Cancer. Clin. Cancer Res. 2013, 19, $3955-3965$. [CrossRef]

131. Hao, H.; Xia, G.; Wang, C.; Zhong, F.; Liu, L.; Zhang, D. miR-106a suppresses tumor cells death in colorectal cancer through targeting ATG. Med. Mol. Morphol. 2016, 50, 76-85. [CrossRef]

132. Bullock, M.D.; Pickard, K.; Mitter, R.; Sayan, A.E.; Primrose, J.N.; Ivan, C.; Calin, G.A.; Thomas, G.J.; Packham, G.K.; Mirnezami, A.H. Stratifying risk of recurrence in stage II colorectal cancer using deregulated stromal and epithelial microRNAs. Oncotarget 2015, 6, 7262-7279. [CrossRef] [PubMed]

133. Chen, W.-Y.; Zhao, X.-J.; Yu, Z.-F.; Hu, F.-L.; Liu, Y.-P.; Cui, B.-B.; Dong, X.-S.; Zhao, Y.-S. The potential of plasma miRNAs for diagnosis and risk estimation of colorectal cancer. Int. J. Clin. Exp. Pathol. 2015, 8, 7092-7101. [PubMed]

134. Riordan, A.M.; Thomas, M.K.; Ronnekleiv-Kelly, S.; Warner, T.; Geiger, P.G.; Kennedy, G.D. Utility of micro-ribonucleic acid profile for predicting recurrence of rectal cancer. J. Surg. Res. 2012, 177, 87-92. [CrossRef] [PubMed]

135. Yamazaki, N.; Koga, Y.; Taniguchi, H.; Kojima, M.; Kanemitsu, Y.; Saito, N.; Matsumura, Y. High expression of miR-181c as a predictive marker of recurrence in stage II colorectal cancer. Oncotarget 2016, 8, 6970-6983. [CrossRef]

136. Liu, G.-H.; Zhou, Z.-G.; Chen, R.; Wang, M.-J.; Zhou, B.; Li, Y.; Sun, X.-F. Serum miR-21 and miR-92a as biomarkers in the diagnosis and prognosis of colorectal cancer. Tumor Biol. 2013, 34, 2175-2181. [CrossRef]

137. Ke, T.-W.; Wei, P.-L.; Yeh, K.-T.; Chen, W.T.-L.; Cheng, Y.-W. MiR-92a Promotes Cell Metastasis of Colorectal Cancer Through PTEN-Mediated PI3K/AKT Pathway. Ann. Surg. Oncol. 2014, 22, 2649-2655. [CrossRef] [PubMed]

138. Wei, Q.-D.; Zheng, W.-B.; Sun, K.; Xue, Q.; Yang, C.-Z.; Li, G.-X. MiR-92a promotes the invasion and migration of colorectal cancer by targeting RECK. Int. J. Clin. Exp. Pathol 2019, 12, 1565-1577.

139. Brînzan, C.; Aşchie, M.; Cozaru, G.; Dumitru, E.; Mitroi, A. The diagnostic value of miR-92a, -143, and -145 expression levels in patients with colorectal adenocarcinoma from Romania. Medicine 2020, 99, e21895. [CrossRef]

140. Slattery, M.L.; Mullany, L.E.; Sakoda, L.C.; Wolff, R.K.; Samowitz, W.S.; Herrick, J.S. Dysregulated genes and miRNAs in the apoptosis pathway in colorectal cancer patients. Apoptosis 2018, 23, 237-250. [CrossRef]

141. Conev, N.; Donev, I.S.; Konsoulova, A.; Chervenkov, T.G.; Kashlov, J.K.; Ivanov, K.D. Serum expression levels of miR-17, miR-21, and miR-92 as potential biomarkers for recurrence after adjuvant chemotherapy in colon cancer patients. Biosci. Trends 2015, 9 , 393-401. [CrossRef] [PubMed]

142. Mullany, L.E.; Herrick, J.S.; Sakoda, L.C.; Samowitz, W.; Stevens, J.R.; Wolff, R.K.; Slattery, M.L. miRNA involvement in cell cycle regulation in colorectal cancer cases. Genes Cancer 2018, 9, 53-65. [CrossRef] [PubMed]

143. Ulivi, P.; Canale, M.; Passardi, A.; Marisi, G.; Valgiusti, M.; Frassineti, G.L.; Calistri, D.; Amadori, D.; Scarpi, E. Circulating Plasma Levels of miR-20b, miR-29b and miR-155 as Predictors of Bevacizumab Efficacy in Patients with Metastatic Colorectal Cancer. Int. J. Mol. Sci. 2018, 19, 307. [CrossRef]

144. Dong, J.; Geng, J.; Tan, W. MiR-363-3p suppresses tumor growth and metastasis of colorectal cancer via targeting SphK2. Biomed. Pharmacother. 2018, 105, 922-931. [CrossRef] [PubMed]

145. Xiao, Z.-G.; Deng, Z.-S.; Zhang, Y.-D.; Huang, Z.-C. Clinical significance of microRNA-93 downregulation in human colon cancer. Eur. J. Gastroenterol. Hepatol. 2013, 25, 296-301. [CrossRef]

146. Yang, I.-P.; Tsai, H.-L.; Miao, Z.-F.; Huang, C.-W.; Kuo, C.-H.; Wu, J.-Y.; Wang, W.-M.; Juo, S.-H.H.; Wang, J.-Y. Development of a deregulating microRNA panel for the detection of early relapse in postoperative colorectal cancer patients. J. Transl. Med. 2016, 14, 108. [CrossRef]

147. Chen, Y.; Wang, G.; Lin, B.; Huang, J. MicroRNA-93-5p expression in tumor tissue and its tumor suppressor function via targeting programmed death ligand-1 in colorectal cancer. Cell Biol. Int. 2020, 44, 1224-1236. [CrossRef] [PubMed]

148. Li, X.; Yang, C.; Wang, X.; Zhang, J.; Zhang, R.; Liu, R. The expression of miR-25 is increased in colorectal cancer and is associated with patient prognosis. Med. Oncol. 2013, 31,1-6. [CrossRef]

149. Li, D.; Zhang, T.; Lai, J.; Zhang, J.; Wang, T.; Ling, Y.; He, S.; Hu, Z. MicroRNA-25/ATXN3 interaction regulates human colon cancer cell growth and migration. Mol. Med. Rep. 2019, 19, 4213-4221. [CrossRef]

150. Ma, Y.; Zhang, P.; Wang, F.; Zhang, H.; Yang, Y.; Shi, C.; Xia, Y.; Peng, J.; Liu, W.; Yang, Z.; et al. Elevated oncofoetal miR-17-5p expression regulates colorectal cancer progression by repressing its target gene P. Nat. Commun. 2012, 3, 1-12. [CrossRef]

151. Fang, L.; Li, H.; Wang, L.; Hu, J.; Jin, T.; Wang, J.; Yang, B.B. MicroRNA-17-5p promotes chemotherapeutic drug resistance and tumour metastasis of colorectal cancer by repressing PTEN expression. Oncotarget 2014, 5, 2974-2987. [CrossRef] [PubMed]

152. Huang, C.; Liu, J.; Xu, L.; Hu, W.; Wang, J.; Wang, M.; Yao, X. MicroRNA-17 promotes cell proliferation and migration in human colorectal cancer by downregulating SIK1. Cancer Manag. Res. 2019, 11, 3521-3534. [CrossRef] [PubMed]

153. Wu, C.-W.; Dong, Y.-J.; Liang, Q.-Y.; He, X.-Q.; Ng, S.S.M.; Chan, F.K.L.; Sung, J.J.Y.; Yu, J. MicroRNA-18a Attenuates DNA Damage Repair through Suppressing the Expression of Ataxia Telangiectasia Mutated in Colorectal Cancer. PLoS ONE 2013, 8, e57036. [CrossRef] [PubMed]

154. Matsumura, T.; Sugimachi, K.; Iinuma, H.; Takahashi, Y.; Kurashige, J.; Sawada, G.; Ueda, M.; Uchi, R.; Ueo, H.; Takano, Y.; et al. Exosomal microRNA in serum is a novel biomarker of recurrence in human colorectal cancer. Br. J. Cancer 2015, 113, $275-281$. [CrossRef] [PubMed]

155. Zhang, G.-J.; Li, Y.; Zhou, H.; Xiao, H.-X.; Zhou, T. miR-20a is an independent prognostic factor in colorectal cancer and is involved in cell metastasis. Mol. Med. Rep. 2014, 10, 283-291. [CrossRef] [PubMed] 
156. Kahlert, C.; Klupp, F.; Brand, K.; Lasitschka, F.; Diederichs, S.; Kirchberg, J.; Rahbari, N.; Dutta, S.; Bork, U.; Fritzmann, J.; et al. Invasion front-specific expression and prognostic significance of microRNA in colorectal liver metastases. Cancer Sci. 2011, 102, 1799-1807. [CrossRef]

157. Cruz-Gil, S.; Sanchez-Martinez, R.; de Cedron, M.G.; Martin-Hernandez, R.; Vargas, T.; Molina, S.; Herranz, J.; Davalos, A.; Reglero, G.; de Molina, A.R. Targeting the lipid metabolic axis ACSL/SCD in colorectal cancer progression by therapeutic miRNAs: miR-19b-1 role. J. Lipid Res. 2018, 59, 14-24. [CrossRef]

158. Xu, M.; Kuang, Y.; Wang, M.; Han, X.; Yang, Q. A microRNA expression signature as a predictor of survival for colon adenocarcinoma. Neoplasma 2017, 64, 56-64. [CrossRef] [PubMed]

159. Li, Z.; Wang, H.; Xu, Z.; Sun, Y.; Han, J. Expression and mechanism of microRNA-181A on incidence and survival in late liver metastases of colorectal cancer. Oncol. Rep. 2016, 35, 1403-1408. [CrossRef]

160. Ji, D.; Chen, Z.; Li, M.; Zhan, T.; Yao, Y.; Zhang, Z.; Xi, J.; Yan, L.; Gu, J. MicroRNA-181a promotes tumor growth and liver metastasis in colorectal cancer by targeting the tumor suppressor WIF-1. Mol. Cancer 2014, 13, 86. [CrossRef]

161. Huang, L.; Wen, C.; Yang, X.; Lou, Q.; Wang, X.; Che, J.; Chen, J.; Yang, Z.; Wu, X.; Huang, M.; et al. PEAK1, acting as a tumor promoter in colorectal cancer, is regulated by the EGFR/KRas signaling axis and miR-181d. Cell Death Dis. 2018, 9, 1-12. [CrossRef] [PubMed]

162. Zhou, T.; Zhang, G.-J.; Zhou, H.; Xiao, H.-X.; Li, Y. Overexpression of microRNA-183 in human colorectal cancer and its clinical significance. Eur. J. Gastroenterol. Hepatol. 2014, 26, 229-233. [CrossRef]

163. Chen, Y.; Song, W. Wnt/catenin $\beta 1 /$ microRNA 183 predicts recurrence and prognosis of patients with colorectal cancer. Oncol. Lett. 2018, 15, 4451-4456. [CrossRef] [PubMed]

164. Zheng, S.; Zhong, Y.-F.; Tan, D.-M.; Xu, Y.; Chen, H.-X.; Wang, D. miR-183-5p enhances the radioresistance of colorectal cancer by directly targeting ATG5. J. Bioscience 2019, 44, 92. [CrossRef]

165. Rapti, S.-M.; Kontos, C.; Papadopoulos, I.N.; Scorilas, A. High miR-96 levels in colorectal adenocarcinoma predict poor prognosis, particularly in patients without distant metastasis at the time of initial diagnosis. Tumor Biol. 2016, 37, 11815-11824. [CrossRef] [PubMed]

166. Sun, Y.; Liu, Y.; Cogdell, D.; Calin, G.A.; Sun, B.; Kopetz, S.; Hamilton, S.R.; Zhang, W. Examining plasma microRNA markers for colorectal cancer at different stages. Oncotarget 2016, 7, 11434-11449. [CrossRef]

167. Ress, A.L.; Stiegelbauer, V.; Winter, E.; Schwarzenbacher, D.; Kiesslich, T.; Lax, S.; Jahn, S.; Deutsch, A.; Bauernhofer, T.; Ling, H.; et al. MiR-96-5p influences cellular growth and is associated with poor survival in colorectal cancer patients. Mol. Carcinog. 2015, 54, 1442-1450. [CrossRef]

168. Wang, S.; Yang, M.H.; Wang, X.Y.; Lin, J.; Ding, Y.Q. Increased expression of miRNA-182 in colorectal carcinoma: An independent and tissue-speciic prognostic factor. Int. J. Clin. Exp. Pathol. 2014, 7, 3498-3503.

169. Liu, H.; Du, L.; Wen, Z.; Yang, Y.; Li, J.; Wang, L.; Zhang, X.; Liu, Y.; Dong, Z.; Li, W.; et al. Up-regulation of miR-182 expression in colorectal cancer tissues and its prognostic value. Int. J. Color. Dis. 2013, 28, 697-703. [CrossRef]

170. Chen, X.-Y.; Zhang, J.; Hou, L.-D.; Zhang, R.; Chen, W.; Fan, H.-N.; Huang, Y.-X.; Liu, H.; Zhu, J.-S. Upregulation of PD-L1 predicts poor prognosis and is associated with miR-191-5p dysregulation in colon adenocarcinoma. Int. J. Immunopathol. Pharmacol. 2018, 32, 1-15. [CrossRef]

171. Xi, Y.; Formentini, A.; Chien, M.; Weir, D.B.; Russo, J.J.; Ju, J.; Kornmann, M.; Ju, J. Prognostic Values of microRNAs in Colorectal Cancer. Biomark. Insights 2006, 1, 113-121. [CrossRef]

172. Roh, M.S.; Lee, H.W.; Jung, S.B.; Kim, K.; Lee, E.H.; Park, M.-I.; Lee, J.S.; Kim, M.-S. Expression of miR-200c and its clinicopathological significance in patients with colorectal cancer. Pathol. Res. Pr. 2018, 214, 350-355. [CrossRef]

173. Toiyama, Y.; Hur, K.; Tanaka, K.; Inoue, Y.; Kusunoki, M.; Boland, C.R.; Goel, A. Serum miR-200c Is a Novel Prognostic and Metastasis-Predictive Biomarker in Patients with Colorectal Cancer. Ann. Surg. 2014, 259, 735-743. [CrossRef]

174. Santasusagna, S.; Moreno, I.; Navarro, A.; Rodenas, F.M.; Hernández, R.; Castellano, J.J.; Muñoz, C.; Monzo, M. Prognostic Impact of miR-200 Family Members in Plasma and Exosomes from Tumor-Draining versus Peripheral Veins of Colon Cancer Patients. Oncology 2018, 95, 309-318. [CrossRef] [PubMed]

175. Tang, R.-Y.; Wang, Z.; Chen, H.-Q.; Zhu, S.-B. Negative Correlation between miR-200c and Decorin Plays an Important Role in the Pathogenesis of Colorectal Carcinoma. BioMed Res. Int. 2017, 2017, 1-8. [CrossRef] [PubMed]

176. Li, W.; Chang, J.; Tong, D.; Peng, J.; Huang, D.; Guo, W.; Zhang, W.; Li, J. Differential microRNA expression profiling in primary tumors and matched liver metastasis of patients with colorectal cancer. Oncotarget 2017, 8, 35783-35791. [CrossRef] [PubMed]

177. Diaz, T.; Tejero, R.; Moreno, I.; Ferrer, G.; Cordeiro, A.; Artells, R.; Navarro, A.; Hernandez, R.; Tapia, G.; Monzo, M. Role of miR-200 family members in survival of colorectal cancer patients treated with fluoropyrimidines. J. Surg. Oncol. 2014, 109, 676-683. [CrossRef]

178. Cheng, H.; Zhang, L.; Cogdell, D.E.; Zheng, H.; Schetter, A.J.; Nykter, M.; Harris, C.C.; Chen, K.; Hamilton, S.R.; Zhang, W. Circulating Plasma MiR-141 Is a Novel Biomarker for Metastatic Colon Cancer and Predicts Poor Prognosis. PLoS ONE 2011, 6, e17745. [CrossRef]

179. Liang, Z.; Li, X.; Liu, S.; Li, C.; Wang, X.; Xing, J. MiR-141-3p inhibits cell proliferation, migration and invasion by targeting TRAF5 in colorectal cancer. Biochem. Biophys. Res. Commun. 2019, 514, 699-705. [CrossRef] 
180. Takano, Y.; Masuda, T.; Iinuma, H.; Yamaguchi, R.; Sato, K.; Tobo, T.; Hirata, H.; Kuroda, Y.; Nambara, S.; Hayashi, N.; et al. Circulating exosomal microRNA-203 is associated with metastasis possibly via inducing tumor-associated macrophages in colorectal cancer. Oncotarget 2017, 8, 78598-78613. [CrossRef]

181. Deng, B.; Wang, B.; Fang, J.; Zhu, X.; Cao, Z.; Lin, Q.; Zhou, L.; Sun, X. MiRNA-203 suppresses cell proliferation, migration and invasion in colorectal cancer via targeting of EIF5A. Sci. Rep. 2016, 6, 28301. [CrossRef]

182. Yuan, K.; Xie, K.; Fox, J.; Zeng, H.; Gao, H.; Huang, C.; Wu, M. Decreased Levels of miR-224 and the Passenger Strand of miR-221 Increase MBD2, Suppressing Maspin and Promoting Colorectal Tumor Growth and Metastasis in Mice. Gastroenterology 2013, 145, 853-864.e9. [CrossRef]

183. Ba, S.; Xuan, Y.; Long, Z.-W.; Chen, H.-Y.; Zheng, S.-S. MicroRNA-27a Promotes the Proliferation and Invasiveness of Colon Cancer Cells by Targeting SFRP1 through the Wnt/ $\beta$-Catenin Signaling Pathway. Cell. Physiol. Biochem. 2017, 42, 1920-1933. [CrossRef]

184. Liang, J.; Tang, J.; Shi, H.; Li, H.; Zhen, T.; Duan, J.; Kang, L.; Zhang, F.; Dong, Y.; Han, A. miR-27a-3p targeting RXR $\alpha$ promotes colorectal cancer progression by activating Wnt/ $\beta$-catenin pathway. Oncotarget 2017, 8, 82991-83008. [CrossRef] [PubMed]

185. Liu, X.; Pan, B.; Sun, L.; Chen, X.; Zeng, K.; Hu, X.; Xu, T.; Xu, M.; Wang, S. Circulating Exosomal miR-27a and miR-130a Act as Novel Diagnostic and Prognostic Biomarkers of Colorectal Cancer. Cancer Epidemiol. Biomark. Prev. 2018, 27, 746-754. [CrossRef] [PubMed]

186. Liu, W.; Qian, K.; Wei, X.; Deng, H.; Zhao, B.; Chen, Q.; Zhang, J.; Liu, H. miR-27a promotes proliferation, migration, and invasion of colorectal cancer by targeting FAM172A and acts as a diagnostic and prognostic biomarker. Oncol. Rep. 2017, 37, 3554-3564. [CrossRef] [PubMed]

187. Kerimis, D.; Kontos, C.; Christodoulou, S.; Papadopoulos, I.N.; Scorilas, A. Elevated expression of miR-24-3p is a potentially adverse prognostic factor in colorectal adenocarcinoma. Clin. Biochem. 2017, 50, 285-292. [CrossRef]

188. Gao, Y.; Liu, Y.; Du, L.; Li, J.; Qu, A.; Zhang, X.; Wang, L.; Wang, C. Down-regulation of miR-24-3p in colorectal cancer is associated with malignant behavior. Med. Oncol. 2014, 32, 1-8. [CrossRef]

189. Inoue, A.; Yamamoto, H.; Uemura, M.; Nishimura, J.; Hata, T.; Takemasa, I.; Ikenaga, M.; Ikeda, M.; Murata, K.; Mizushima, T.; et al. MicroRNA-29b is a Novel Prognostic Marker in Colorectal Cancer. Ann. Surg. Oncol. 2015, 22, 1410-1418. [CrossRef]

190. Tang, W.; Zhu, Y.; Gao, J.; Fu, J.; Liu, C.; Liu, Y.; Song, C.; Zhu, S.; Leng, Y.; Wang, G.; et al. MicroRNA-29a promotes colorectal cancer metastasis by regulating matrix metalloproteinase 2 and E-cadherin via KLF. Br. J. Cancer 2014, 110, 450-458. [CrossRef]

191. Kuo, T.-Y.; Hsi, E.; Yang, I.-P.; Tsai, P.-C.; Wang, J.-Y.; Juo, S.-H.H. Computational Analysis of mRNA Expression Profiles Identifies MicroRNA-29a/c as Predictor of Colorectal Cancer Early Recurrence. PLoS ONE 2012, 7, e31587. [CrossRef] [PubMed]

192. Yuan, Z.; Baker, K.; Redman, M.W.; Wang, L.; Adams, S.V.; Yu, M.; Dickinson, B.; Makar, K.; Ulrich, N.; Böhm, J.; et al. Dynamic plasma microRNAs are biomarkers for prognosis and early detection of recurrence in colorectal cancer. Br. J. Cancer 2017, 117, 1202-1210. [CrossRef]

193. Aharonov, R.; Weissmann-Brenner, A.; Kushnir, M.; Yanai, G.L.; Gibori, H.; Purim, O.; Kundel, Y.; Morgenstern, S.; Halperin, M.; Niv, Y.; et al. Tumor microRNA-29a expression and the risk of recurrence in stage II colon cancer. Int. J. Oncol. 2012, 40, 2097-2103. [CrossRef]

194. Colangelo, T.; Fucci, A.; Votino, C.; Sabatino, L.; Pancione, M.; Laudanna, C.; Binaschi, M.; Bigioni, M.; Maggi, C.A.; Parente, D.; et al. MicroRNA-130b Promotes Tumor Development and Is Associated with Poor Prognosis in Colorectal Cancer. Neoplasia 2013, 15, 1086-1099. [CrossRef]

195. Li, T.; Jian, X.; He, H.; Lai, Q.; Li, X.; Deng, D.; Liu, T.; Zhu, J.; Jiao, H.; Ye, Y.; et al. MiR-452 promotes an aggressive colorectal cancer phenotype by regulating a Wnt/ $\beta$-catenin positive feedback loop. J. Exp. Clin. Cancer Res. 2018, 37, 238. [CrossRef]

196. Yan, J.; Wei, R.; Li, H.; Dou, Y.; Wang, J. miR-452-5p and miR-215-5p expression levels in colorectal cancer tissues and their relationship with clinicopathological features. Oncol. Lett. 2020, 20, 2955-2961. [CrossRef] [PubMed]

197. Adamopoulos, P.G.; Kontos, C.K.; Rapti, S.-M.; Papadopoulos, I.N.; Scorilas, A. miR-224 overexpression is a strong and independent prognosticator of short-term relapse and poor overall survival in colorectal adenocarcinoma. Int. J. Oncol. 2014, 46, 849-859. [CrossRef] [PubMed]

198. Ling, H.; Pickard, K.; Ivan, C.; Isella, C.; Ikuo, M.; Mitter, R.; Spizzo, R.; Bullock, M.D.; Braicu, C.; Pileczki, V.; et al. The clinical and biological significance of MIR-224 expression in colorectal cancer metastasis. Gut 2016, 65, 977-989. [CrossRef] [PubMed]

199. Conteduca, V.; Sansonno, D.; Russi, S.; Dammacco, F. Precancerous colorectal lesions. Int. J. Oncol. 1943, 43, 973-984. [CrossRef] [PubMed]

200. Gupta, R.; Sinha, S.; Paul, R.N. The impact of microsatellite stability status in colorectal cancer. Curr. Probl. Cancer 2018, 42, 548-559. [CrossRef] [PubMed]

201. Gelsomino, F.; Barbolini, M.; Spallanzani, A.; Pugliese, G.; Cascinu, S. The evolving role of microsatellite instability in colorectal cancer: A review. Cancer Treat. Rev. 2016, 51, 19-26. [CrossRef]

202. Earle, J.S.; Luthra, R.; Romans, A.; Abraham, R.; Ensor, J.; Yao, H.; Hamilton, S.R. Association of MicroRNA Expression with Microsatellite Instability Status in Colorectal Adenocarcinoma. J. Mol. Diagn. 2010, 12, 433-440. [CrossRef]

203. Blondy, S.; David, V.; Verdier, M.; Mathonnet, M.; Perraud, A.; Christou, N. 5-Fluorouracil resistance mechanisms in colorectal cancer: From classical pathways to promising processes. Cancer Sci. 2020, 111, 3142-3154. [CrossRef] [PubMed] 
204. Longley, D.B.; Harkin, D.P.; Johnston, P.G. 5-Fluorouracil: Mechanisms of action and clinical strategies. Nat. Rev. Cancer 2003, 3, 330-338. [CrossRef]

205. Martinez-Balibrea, E.; Martínez-Cardús, A.; Ginés, A.; De Porras, V.R.; Moutinho, C.; Layos, L.; Manzano, J.L.; Bugés, C.; Bystrup, S.; Esteller, M.; et al. Tumor-Related Molecular Mechanisms of Oxaliplatin Resistance. Mol. Cancer Ther. 2015, 14, 1767-1776. [CrossRef] [PubMed]

206. Vaghari-Tabari, M.; Majidinia, M.; Moein, S.; Qujeq, D.; Asemi, Z.; Alemi, F.; Mohamadzadeh, R.; Targhazeh, N.; Safa, A.; Yousefi, B. MicroRNAs and colorectal cancer chemoresistance: New solution for old problem. Life Sci. 2020, $259,118255$. [CrossRef]

207. Barisciano, G.; Colangelo, T.; Rosato, V.; Muccillo, L.; Taddei, M.L.; Ippolito, L.; Chiarugi, P.; Galgani, M.; Bruzzaniti, S.; Matarese, G.; et al. miR-27a is a master regulator of metabolic reprogramming and chemoresistance in colorectal cancer. $\mathrm{Br}$. J. Cancer 2020, 122, 1354-1366. [CrossRef] [PubMed]

208. Fu, Q.; Cheng, J.; Zhang, J.; Zhang, Y.; Chen, X.; Luo, S.; Xie, J. miR-20b reduces 5-FU resistance by suppressing the ADAM9/EGFR signaling pathway in colon cancer. Oncol. Rep. 2017, 37, 123-130. [CrossRef] [PubMed]

209. Liu, J.; Huang, Y.; Wang, H.; Wu, D. MiR-106a-5p promotes 5-FU resistance and the metastasis of colorectal cancer by targeting TGFßR2. Int. J. Clin. Exp. Pathol 2018, 11, 5622-5634. [PubMed]

210. Zhang, G.-J.; Li, L.-F.; Yang, G.-D.; Xia, S.-S.; Wang, R.; Leng, Z.-W.; Liu, Z.-L.; Tian, H.-P.; He, Y.; Meng, C.-Y.; et al. MiR-92a promotes stem cell-like properties by activating Wnt/ $\beta$-catenin signaling in colorectal cancer. Oncotarget 2017, 8, 101760-101770. [CrossRef]

211. Zhang, J.; Zhang, K.; Bi, M.; Jiao, X.; Zhang, D.; Dong, Q. Circulating microRNA expressions in colorectal cancer as predictors of response to chemotherapy. Anti-Cancer Drugs 2014, 25, 346-352. [CrossRef]

212. Chen, Q.; Xia, H.-W.; Ge, X.-J.; Zhang, Y.-C.; Tang, Q.-L.; Bi, F. Serum miR-19a Predicts Resistance to FOLFOX Chemotherapy in Advanced Colorectal Cancer Cases. Asian Pac. J. Cancer Prev. 2013, 14, 7421-7426. [CrossRef]

213. Jin, G.; Liu, Y.; Zhang, J.; Bian, Z.; Yao, S.; Fei, B.; Zhou, L.; Yin, Y.; Huang, Z. A panel of serum exosomal microRNAs as predictive markers for chemoresistance in advanced colorectal cancer. Cancer Chemother. Pharmacol. 2019, 84, 315-325. [CrossRef]

214. Kjersem, J.; Ikdahl, T.; Lingjaerde, O.; Guren, T.; Tveit, K.; Kure, E. Plasma microRNAs predicting clinical outcome in metastatic colorectal cancer patients receiving first-line oxaliplatin-based treatment. Mol. Oncol. 2013, 8, 59-67. [CrossRef]

215. Shang, J.; Yang, F.; Wang, Y.; Wang, Y.; Xue, G.; Mei, Q.; Wang, F.; Sun, S. MicroRNA-23a Antisense Enhances 5-Fluorouracil Chemosensitivity Through APAF-1/Caspase-9 Apoptotic Pathway in Colorectal Cancer Cells. J. Cell. Biochem. 2014, 115, 772-784. [CrossRef]

216. Balacescu, O.; Sur, D.; Cainap, C.; Visan, S.; Cruceriu, D.; Manzat-Saplacan, R.; Muresan, M.-S.; Balacescu, L.; Lisencu, C.; Irimie, A. The Impact of miRNA in Colorectal Cancer Progression and Its Liver Metastases. Int. J. Mol. Sci. 2018, $19,3711$. [CrossRef]

217. Saberinia, A.; Alinezhad, A.; Jafari, F.; Soltany, S.; Sigari, R.A. Oncogenic miRNAs and target therapies in colorectal cancer. Clin. Chim. Acta 2020, 508, 77-91. [CrossRef]

218. Ding, L.; Lan, Z.; Xiong, X.; Ao, H.; Feng, Y.; Gu, H.; Yu, M.; Cui, Q. The Dual Role of MicroRNAs in Colorectal Cancer Progression. Int. J. Mol. Sci. 2018, 19, 2791. [CrossRef]

219. Tripathi, S.; Flobak, Å.; Chawla, K.; Baudot, A.; Bruland, T.; Thommesen, L.; Kuiper, M.T.R.; Lægreid, A. The gastrin and cholecystokinin receptors mediated signaling network: A scaffold for data analysis and new hypotheses on regulatory mechanisms. $B M C$ Syst. Biol. 2015, 9, 1-15. [CrossRef]

220. Gao, F.; Wang, W. MicroRNA-96 promotes the proliferation of colorectal cancer cells and targets tumor protein p53 inducible nuclear protein 1, forkhead box protein O1 (FOXO1) and FOXO3a. Mol. Med. Rep. 2015, 11, 1200-1206. [CrossRef]

221. Li, T.; Lai, Q.; Wang, S.; Cai, J.; Xiao, Z.; Deng, D.; He, L.; Jiao, H.; Ye, Y.; Liang, L.; et al. MicroRNA-224 sustains Wnt/ $\beta$-catenin signaling and promotes aggressive phenotype of colorectal cancer. J. Exp. Clin. Cancer Res. 2016, 35, 1-11. [CrossRef]

222. Tang, Q.; Zou, Z.; Zou, C.; Zhang, Q.; Huang, R.; Guan, X.; Li, Q.; Han, Z.; Wang, D.; Wei, H.; et al. MicroRNA-93 suppress colorectal cancer development via Wnt/ $\beta$-catenin pathway downregulating. Tumor Biol. 2014, 36, 1701-1710. [CrossRef]

223. Huang, W.; Tian, Y.; Dong, S.; Cha, Y.; Li, J.; Guo, X.; Yuan, X. The long non-coding RNA SNHG3 functions as a competing endogenous RNA to promote malignant development of colorectal cancer. Oncol. Rep. 2017, 38, 1402-1410. [CrossRef]

224. Humphreys, K.J.; McKinnon, R.A.; Michael, M.Z. miR-18a Inhibits CDC42 and Plays a Tumour Suppressor Role in Colorectal Cancer Cells. PLoS ONE 2014, 9, e112288. [CrossRef]

225. Shah, M.S.; Kim, E.; Davidson, L.A.; Knight, J.M.; Zoh, R.S.; Goldsby, J.S.; Callaway, E.S.; Zhou, B.; Ivanov, I.; Chapkin, R.S. Comparative effects of diet and carcinogen on microRNA expression in the stem cell niche of the mouse colonic crypt. Biochim. Biophys. Acta Mol. Basis Dis. 2016, 1862, 121-134. [CrossRef]

226. Zhong, X.; Xiao, Y.; Chen, C.; Wei, X.; Hu, C.; Ling, X.; Liu, X. MicroRNA-203-mediated posttranscriptional deregulation of CPEB4 contributes to colorectal cancer progression. Biochem. Biophys. Res. Commun. 2015, 466, 206-213. [CrossRef]

227. Jiang, T.; Ye, L.; Han, Z.; Liu, Y.; Yang, Y.; Peng, Z.; Fan, J. miR-19b-3p promotes colon cancer proliferation and oxaliplatin-based chemoresistance by targeting SMAD4: Validation by bioinformatics and experimental analyses. J. Exp. Clin. Cancer Res. 2017, 36, 1-14. [CrossRef] 
228. Dews, M.; Fox, J.L.; Hultine, S.; Sundaram, P.; Wang, W.; Liu, Y.Y.; Furth, E.E.; Enders, G.H.; Eldeiry, W.S.; Schelter, J.M.; et al. The Myc-miR-17 92 Axis Blunts TGF $\beta$ Signaling and Production of Multiple TGF $\beta$-Dependent Antiangiogenic Factors. Cancer Res. 2010, 70, 8233-8246. [CrossRef]

229. Chen, M.; Lin, M.; Wang, X. Overexpression of miR-19a inhibits colorectal cancer angiogenesis by suppressing KRAS expression. Oncol. Rep. 2017, 39, 619-626. [CrossRef]

230. Ma, H.; Pan, J.-S.; Jin, L.-X.; Wu, J.; Ren, Y.-D.; Chen, P.; Xiao, C.; Han, J. MicroRNA-17 92 inhibits colorectal cancer progression by targeting angiogenesis. Cancer Lett. 2016, 376, 293-302. [CrossRef]

231. Farooqi, A.A.; de la Roche, M.; Djamgoz, M.B.; Siddik, Z.H. Overview of the oncogenic signaling pathways in colorectal cancer: Mechanistic insights. Semin. Cancer Biol. 2019, 58, 65-79. [CrossRef]

232. Zhou, Y.; Wan, G.; Spizzo, R.; Ivan, C.; Mathur, R.; Hu, X.; Ye, X.; Lu, J.; Fan, F.; Xia, L.; et al. miR-203 induces oxaliplatin resistance in colorectal cancer cells by negatively regulating ATM kinase. Mol. Oncol. 2013, 8, 83-92. [CrossRef] [PubMed]

233. Zhang, X.; Zhang, X.; Liu, C.; Jia, N.; Li, X.; Xiao, J. miR-224 promotes colorectal cancer cells proliferation via downregulation of P21WAF1/CIP1. Mol. Med. Rep. 2014, 9, 941-946. [CrossRef] [PubMed]

234. Zheng, L.; Zhang, Y.; Liu, Y.; Zhou, M.; Lu, Y.; Yuan, L.; Zhang, C.; Hong, M.; Wang, S.; Li, X. MiR-106b induces cell radioresistance via the PTEN/PI3K/AKT pathways and p21 in colorectal cancer. J. Transl. Med. 2015, 13, 1-13. [CrossRef] [PubMed]

235. Sokolova, V.; Fiorino, A.; Zoni, E.; Crippa, E.; Reid, J.F.; Gariboldi, M.; Pierotti, M.A. The Effects of miR-20a on p21: Two Mechanisms Blocking Growth Arrest in TGF- $\beta$-Responsive Colon Carcinoma. J. Cell. Physiol. 2015, 230, 3105-3114. [CrossRef]

236. Yin, Q.; Wang, P.-P.; Peng, R.; Zhou, H. MiR-19a enhances cell proliferation, migration, and invasiveness through enhancing lymphangiogenesis by targeting thrombospondin-1 in colorectal cancer. Biochem. Cell Biol. 2019, 97, 731-739. [CrossRef]

237. Amodeo, V.; Bazan, V.; Fanale, D.; Insalaco, L.; Caruso, S.; Cicero, G.; Bronte, G.; Rolfo, C.; Santini, D.; Russo, A. Effects of anti-miR-182 on TSP-1 expression in human colon cancer cells: There is a sense in antisense? Expert Opin. Ther. Targets 2013, 17, 1249-1261. [CrossRef]

238. Qian, Z.; Gong, L.; Mou, Y.; Han, Y.; Zheng, S. MicroRNA-203a-3p is a candidate tumor suppressor that targets thrombospondin 2 in colorectal carcinoma. Oncol. Rep. 2019, 42, 1825-1832. [CrossRef]

239. Liu, H.; Cheng, X.-H. MiR-29b reverses oxaliplatin-resistance in colorectal cancer by targeting SIRT1. Oncotarget 2018, 9, 12304-12315. [CrossRef]

240. Chen, H.; Lu, W.; Huang, C.; Ding, K.; Xia, D.; Wu, Y.; Cai, M. Prognostic significance of ZEB1 and ZEB2 in digestive cancers: A cohort-based analysis and secondary analysis. Oncotarget 2017, 8, 31435-31448. [CrossRef]

241. Chen, J.; Wang, Y.; Zhuo, L.; Liu, Z.; Liu, T.; Li, W.; Cai, Y.; Zheng, H. Fas signaling induces stemness properties in colorectal cancer by regulation of Bmi1. Mol. Carcinog. 2017, 56, 2267-2278. [CrossRef] [PubMed]

242. Li, X.L.; Hara, T.; Choi, Y.; Subramanian, M.; Francis, P.; Bilke, S.; Walker, R.L.; Pineda, M.; Zhu, Y.; Yang, Y.; et al. A p21-ZEB1 Complex Inhibits Epithelial-Mesenchymal Transition through the MicroRNA 183-96-182 Cluster. Mol. Cell. Biol. 2014, 34, 533-550. [CrossRef] [PubMed]

243. Hozhabri, H.; Lashkari, A.; Razavi, S.-M.; Mohammadian, A. Integration of gene expression data identifies key genes and pathways in colorectal cancer. Med. Oncol. 2021, 38, 1-14. [CrossRef] [PubMed]

244. Mastrogamvraki, N.; Zaravinos, A. Signatures of co-deregulated genes and their transcriptional regulators in colorectal cancer. NPJ Syst. Biol. Appl. 2020, 6, 1-16. [CrossRef]

245. Kim, H.-Y.; Kim, Y.-M.; Hong, S. Astaxanthin suppresses the metastasis of colon cancer by inhibiting the MYC-mediated downregulation of microRNA-29a-3p and microRNA-200a. Sci. Rep. 2019, 9, 1-10. [CrossRef]

246. Hu, S.; Liu, L.; Chang, E.B.; Wang, J.-Y.; Raufman, J.-P. Butyrate inhibits pro-proliferative miR-92a by diminishing c-Myc-induced miR-17-92a cluster transcription in human colon cancer cells. Mol. Cancer 2015, 14, 1-15. [CrossRef]

247. Guo, Y.; Ye, Q.; Deng, P.; Cao, Y.; He, D.; Zhou, Z.; Wang, C.; Zaytseva, Y.Y.; Schwartz, C.E.; Lee, E.Y.; et al. Spermine synthase and MYC cooperate to maintain colorectal cancer cell survival by repressing Bim expression. Nat. Commun. 2020, 11, 1-16. [CrossRef]

248. Strippoli, A.; Cocomazzi, A.; Basso, M.; Cenci, T.; Ricci, R.; Pierconti, F.; Cassano, A.; Fiorentino, V.; Barone, C.; Bria, E.; et al. c-MYC Expression Is a Possible Keystone in the Colorectal Cancer Resistance to EGFR Inhibitors. Cancers 2020, 12, 638. [CrossRef]

249. Lee, K.S.; Kwak, Y.; Nam, K.H.; Kim, D.-W.; Kang, S.-B.; Choe, G.; Kim, W.H.; Lee, H.S. Favorable prognosis in colorectal cancer patients with co-expression of c-MYC and B-catenin. BMC Cancer 2016, 16, 1-12. [CrossRef]

250. Wang, J.; Lu, M.; Qiu, C.; Cui, Q. TransmiR: A transcription factor-microRNA regulation database. Nucleic Acids Res. 2009, 38, D119-D122. [CrossRef]

251. Tong, Z.; Cui, Q.; Wang, J.; Zhou, Y. TransmiR v2.0: An updated transcription factor-microRNA regulation database. Nucleic Acids Res. 2019, 47, D253-D258. [CrossRef] [PubMed]

252. Seth, A.; Watson, D.K. ETS transcription factors and their emerging roles in human cancer. Eur. J. Cancer 2005, 41, $2462-2478$. [CrossRef]

253. Melotte, V.; Qu, X.; Ongenaert, M.; Van Criekinge, W.; De Bruine, A.P.; Baldwin, H.S.; Van Engeland, M. The N-myc downstream regulated gene (NDRG) family: Diverse functions, multiple applications. FASEB J. 2010, 24, 4153-4166. [CrossRef]

254. Wang, X.; Sun, D.; Tai, J.; Chen, S.; Yu, M.; Ren, D.; Wang, L. TFAP2C promotes stemness and chemotherapeutic resistance in colorectal cancer via inactivating hippo signaling pathway. J. Exp. Clin. Cancer Res. 2018, 37, 1-16. [CrossRef] 
255. Wu, C.W.; Evans, J.M.; Huang, S.; Mahoney, D.W.; Dukek, B.A.; Taylor, W.R.; Yab, T.C.; Smyrk, T.C.; Jen, J.; Kisiel, J.B.; et al. A Comprehensive Approach to Sequence-oriented IsomiR annotation (CASMIR): Demonstration with IsomiR profiling in colorectal neoplasia. BMC Genom. 2018, 19, 401. [CrossRef]

256. Shkurnikov, M.Y.; Nersisyan, S.A.; Osepyan, A.S.; Maltseva, D.V.; Knyazev, E.N. Differences in the Drosha and Dicer Cleavage Profiles in Colorectal Cancer and Normal Colon Tissue Samples. Dokl. Biochem. Biophys. 2020, 493, 208-210. [CrossRef]

257. Na, Y.-J.; Sung, J.H.; Lee, S.C.; Lee, Y.-J.; Choi, Y.J.; Park, W.-Y.; Shin, H.S.; Kim, J.H. Comprehensive analysis of microRNA-mRNA co-expression in circadian rhythm. Exp. Mol. Med. 2009, 41, 638-647. [CrossRef] [PubMed]

258. Balakrishnan, A.; Stearns, A.T.; Park, P.J.; Dreyfuss, J.M.; Ashley, S.W.; Rhoads, D.B.; Tavakkolizadeh, A. MicroRNA mir-16 is anti-proliferative in enterocytes and exhibits diurnal rhythmicity in intestinal crypts. Exp. Cell Res. 2010, 316, 3512-3521. [CrossRef]

259. Kinoshita, C.; Aoyama, K.; Matsumura, N.; Kikuchi-Utsumi, K.; Watabe, M.; Nakaki, T. Rhythmic oscillations of the microRNA miR-96-5p play a neuroprotective role by indirectly regulating glutathione levels. Nat. Commun. 2014, 5, 3823. [CrossRef]

260. Heegaard, N.H.H.; Carlsen, A.L.; Lilje, B.; Ng, K.L.; Rønne, M.E.; Jørgensen, H.L.; Sennels, H.; Fahrenkrug, J. Diurnal Variations of Human Circulating Cell-Free Micro-RNA. PLoS ONE 2016, 11, e0160577. [CrossRef]

261. Xu, H.; Ma, Y.; Zhang, J.; Gu, J.; Jing, X.; Lu, S.; Fu, S.; Huo, J. Identification and Verification of Core Genes in Colorectal Cancer. BioMed Res. Int. 2020, 2020, 1-13. [CrossRef]

262. Guo, Y.; Bao, Y.; Ma, M.; Yang, W. Identification of Key Candidate Genes and Pathways in Colorectal Cancer by Integrated Bioinformatical Analysis. Int. J. Mol. Sci. 2017, 18, 722. [CrossRef]

263. Chen, X.; Shi, K.; Wang, Y.; Song, M.; Zhou, W.; Tu, H.; Lin, Z. Clinical value of integrated-signature miRNAs in colorectal cancer: miRNA expression profiling analysis and experimental validation. Oncotarget 2015, 6, 37544-37556. [CrossRef]

264. Francavilla, A.; Turoczi, S.; Tarallo, S.; Vodicka, P.; Pardini, B.; Naccarati, A. Exosomal microRNAs and other non-coding RNAs as colorectal cancer biomarkers: A review. Mutagenetics 2019, 35, 243-260. [CrossRef]

265. Sempere, L.F.; Azmi, A.S.; Moore, A. microRNA -based diagnostic and therapeutic applications in cancer medicine. Wiley Interdiscip. Rev. RNA 2021, e1662. [CrossRef]

266. Ratti, M.; Lampis, A.; Ghidini, M.; Salati, M.; Mirchev, M.B.; Valeri, N.; Hahne, J.C. MicroRNAs (miRNAs) and Long Non-Coding RNAs (lncRNAs) as New Tools for Cancer Therapy: First Steps from Bench to Bedside. Target. Oncol. 2020, 15, 261-278. [CrossRef]

267. Chakraborty, C.; Sharma, A.R.; Sharma, G.; Lee, S.-S. Therapeutic advances of miRNAs: A preclinical and clinical update. J. Adv. Res. 2021, 28, 127-138. [CrossRef]

268. Matsuyama, H.; Suzuki, H.I. Systems and Synthetic microRNA Biology: From Biogenesis to Disease Pathogenesis. Int. J. Mol. Sci. 2019, 21, 132. [CrossRef]

269. Gregorova, J.; Vychytilova-Faltejskova, P.; Sevcikova, S. Epigenetic Regulation of MicroRNA Clusters and Families during Tumor Development. Cancers 2021, 13, 1333. [CrossRef] 